\begin{tabular}{|c|c|c|c|c|c|c|}
\hline \multirow{4}{*}{ Impact Factor: } & ISRA (India) & $=3.117$ & SIS (USA) & $=0.912$ & ICV (Poland) & $=6.630$ \\
\hline & ISI (Dubai, UAE & $=0.829$ & РИНЦ (Russia & $=0.156$ & PIF (India) & $=1.940$ \\
\hline & GIF (Australia) & $=0.564$ & ESJI (KZ) & $=8.716$ & IBI (India) & $=4.260$ \\
\hline & JIF & $=1.500$ & SJIF (Morocco & $=5.667$ & OAJI (USA) & $=0.350$ \\
\hline
\end{tabular}

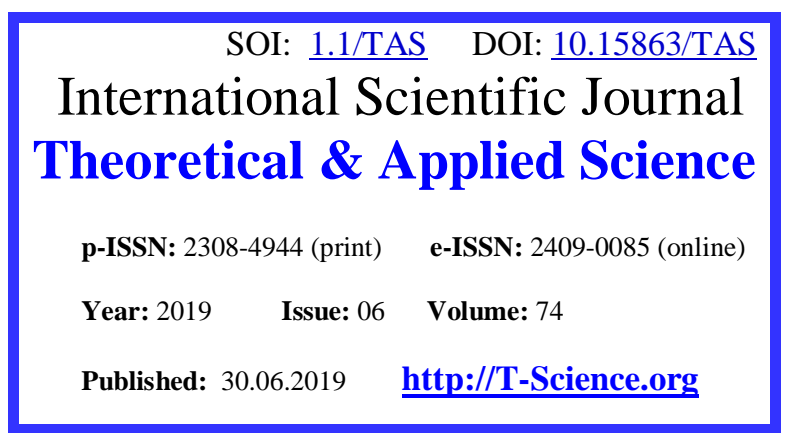

SECTION 31. Economic research, finance, innovation, risk management.

UDC 685.17: 335.46

\section{QR - Issue}
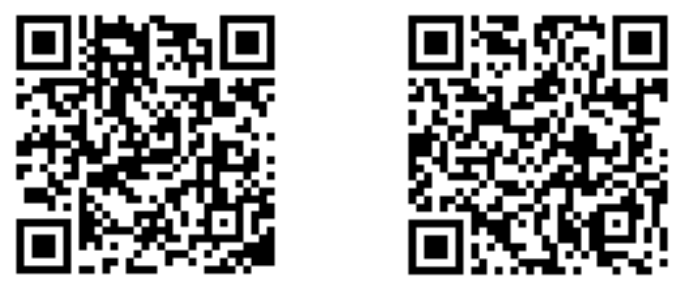

Artur Alexandrovich Blagorodov Institute of Entrepreneurship and Service sector (branch)

DSTU

bachelor, g. Shakhty

blaghorodov@list.ru

Dmitri Olegovich Bordukh

Institute of Entrepreneurship and Service sector (branch)

DSTU

bachelor, g. Shakhty bordukh95@bk.ru

Angelina Vladimirovna Kopylova Institute of Entrepreneurship and Service sector (branch)

DSTU

bachelor, g. Shakhty angelinakopylova22121999@mail.ru

Vladimir Timofeevich Prokhorov ISOP (f) DGTU

Doctor of technical sciences, professor, professor of the department "Designing, technology and design", Shakhty prohorov@sssu.ru

Igor Mikhailovich Maltsev Institute of Entrepreneurship and Sevice sector (branch) DSTU associate Professor, Ph. D.-m H., g. Shakhty

Natalia Vassilievna Tikhonova Kazan national research technological University Doctor of technical sciences, professor Kazan, Republic of Tatarstan

\title{
OPPORTUNITIES OF COMPETITIVE ADVANTAGES OF THE MADE IMPORT-SUBSTITUTING PRODUCTION ON THE BASIS OF THE ANALYSIS OF DEMAND FOR ITS DEMAND BY CONSUMERS OF REGIONS OF SOUTHERN FEDERAL DISTRICT AND SKFO
}

Abstract: The article discusses the possibility of the production of competitive and marketable products, which are possible only if managers are professionally trained and politically responsible for its performance. The authors rightly believe that the political responsibility of heads of enterprises lYe with gravesoftwood industry and it is the highest expression of the measure of their professionals. But at the same time I would like to note that the nonfulfillment of political promises and statements - is evidence of either their inability to engage in economic policy, or the use of political governance is carried out by them in their own interests that are alien to the interests of society, provoking the impoverishment of the people, describing immorality leaders, which of course is unacceptable. And it is clear that there are no objective reasons that would justify the decline in production in the lYe with gravesoftwood 


\begin{tabular}{|c|c|c|c|c|c|c|}
\hline \multirow{4}{*}{ Impact Factor: } & ISRA (India) & $=3.117$ & SIS (USA) & $=0.912$ & ICV (Poland) & $=6.630$ \\
\hline & ISI (Dubai, UAI & $=0.829$ & РИНЦ (Russia & $=0.156$ & PIF (India) & $=1.940$ \\
\hline & GIF (Australia) & $=0.564$ & ESJI (KZ) & $=8.716$ & IBI (India) & $=4.260$ \\
\hline & JIF & $=1.500$ & SJIF (Morocco & $=5.667$ & OAJI (USA) & $=0.350$ \\
\hline
\end{tabular}

industry, and therefore economic policy evaluation results should be either beneficial or harmful - it should always be an axiom. If it does not, then something is in that same economic policy is not a professional solution, actions harmful to society and require timely adjustments. The authors recommend the market to reconsider the concept of the formation of his demand and import substitution based on their attractiveness. Such a concept would fully meet the customer's request to meet his desire and the desire to make a purchase based on their social status, allowing manufacturers to implement sustainable TPE manufactured their products in full and ensuring their businesses activities.

Key words: competitiveness, relevance, innovation and innovative activity, a decline in production, a useful economic policy, harmful economic policies, professional solutions, immorality, political responsibility, professional trained managers, profit, profitability, break-even, high performance TPE, high creative potential of specialists.

Language: English

Citation: Blagorodov, A. A., Bordukh, D. O., Kopylova, A. V., Prokhorov, V. T., Maltsev, I. M., \& Tikhonova, N. V. (2019). Opportunities of competitive advantages of the made import-substituting production on the basis of the analysis of demand for its demand by consumers of regions of southern Federal district and skfo. ISJ Theoretical \& Applied Science, 06 (74), 662-692.

Soi: http://s-o-i.org/1.1/TAS-06-74-85 Doi: crossef https://dx.doi.org/10.15863/TAS.2019.06.74.85

\section{Introduction}

Integration, globalization - not a panacea for development. They do not cancel the competition in which the winners are not alone. More losers. Hence the relevance of the old truth, the meaning of which became clear in the dialectic. Movement in all conditions becomes a self-movement. Chinese rationally closed themselves and won. The victory ensured them: Eastern cautious and skeptical attitude toward unification. They used to have realized that integration and globalization are varieties of "pyramids" and conditionally useful for national development. From the side it might seem that Chinese reformers rejected the mentality of the curse: "you to live in a time of change." From the inside it looked traditionally - politicians do not betray a sharp movement on a national scale, in a hurry, but with constant reference to the actions of the state economic structure, reforms in the economy subordinated the traditional political dominants not repented and tried to please. About any economic shocks no one seriously thought. Finance as the circulatory system of the economic organism took "echinoid state gloves", entered the tightening of economic and corruptionrelated crimes, equating to a lot of them to dangerous actions against the State, did not come up with new games - update available, as always paid special attention to personnel policy. The Chinese have taken into account the experience of the Soviet party "growing" frame, which is based on the principle of steady progress, depending on the efficiency of business and lifestyle. Finance as the circulatory system of the economic organism took "echinoid state gloves", entered the tightening of economic and corruption-related crimes, equating to a lot of them to dangerous actions against the State, did not come up with new games - update available, as always paid special attention to personnel policy. The Chinese have taken into account the experience of the Soviet party "growing" frame, which is based on the principle of steady progress, depending on the efficiency of business and lifestyle. Finance as the circulatory system of the economic organism took "echinoid state gloves", entered the tightening of economic and corruption-related crimes, equating to a lot of them to dangerous actions against the State, did not come up with new games - update available, as always paid special attention to personnel policy. The Chinese have taken into account the experience of the Soviet party "growing" frame, which is based on the principle of steady progress, depending on the efficiency of business and lifestyle.

\section{Main part.}

In the seventy years of Soviet history were isolated cases, when the management of the economy turned out to random people. They could be just coincidence, confirming its exclusivity, the personnel capacity of the political paradigm. Taking into account the economic disadvantages of excessive centralization in the management of the economy, can afford the following thesis - socialist economies of the Soviet type was not rationally constructed, but it contained a substantial reserve, which gave an opportunity to the new revolutionaries did not repeat the old Bolshevik techniques - to help one and rob others.

The Bolsheviks in the image of the revolutionaries look for all the odious policy of nationalization of property in a more favorable light in comparison with those in the 1990 squandered a national treasure and are extremely reluctant to change their interested attitude to what is happening today. The outcome of the revolution of 1917 was the industrialization and the rise of light industry, crafts, the result of the counter-revolution - 25-year-old depressed economy, the struggle for survival of the textile, shoe, garment production, the decline in the organization of training of qualified personnel across the spectrum - from workers to engineering specialties. In such circumstances, it is time to withdraw from the abstract political ideals demreformatorov and came to develop a "road map" revival of light industry in the hope that the crisis 


\begin{tabular}{|c|c|c|c|c|c|c|}
\hline \multirow{4}{*}{ Impact Factor: } & ISRA (India) & $=3.117$ & SIS (USA) & $=0.912$ & ICV (Poland) & $=6.630$ \\
\hline & ISI (Dubai, UAI & $=0.829$ & РИНЦ (Russia & $=0.156$ & PIF (India) & $=1.940$ \\
\hline & GIF (Australia) & $=0.564$ & ESJI (KZ) & $=8.716$ & IBI (India) & $=4.260$ \\
\hline & JIF & $=1.500$ & SJIF (Morocco & $=5.667$ & OAJI (USA) & $=0.350$ \\
\hline
\end{tabular}

highlights the urgency of reasonableness "brainstorming" as opposed to "New Economic School" in the trend. What is the road "map" it appears to be based on the historical experience of the XX century, when there were all major events.

1. The priority of sustainability must be the interests of national advancement. On the development of a very, I would say, but it is on a national scale is not to get. We need to "lick their wounds". At present, the most economically optimistic estimate is in pursuit of a sustainable stabilization of the economic indicators. Doctors in a similar situation are encouraging: Condition "serious but stable" Unfortunately, the economy can not be entered in the "artificial coma" to help overcome the crisis through a more economical expenditure of vitality. We are the first point of the "road map" that's what interested. Doctors seek to mobilize the potential of the life of the body, help to reveal the stock will to live. Our economy is able to fight for survival, there are many smart, knowledgeable, dedicated patriots, however, every year lost their number decreases. According to Doctor of Economics, professor of NRU "Higher School of Economics" V. Inozemtsev - one of the regular contributors AIF, annual leave from the country about 400 thousand people. Naturally, not all on permanent, someone working on a contract, in search of temporary work. In the first place to help people energetic, light them the green light at the end of the tunnel. Rely on the established officials in a quarter-century type of confidence that is not the sword of justice hanging over them, and a safe senior bureaucrat to receive compensation, it is not necessary. Option - ONF. President and regularly communicates with its interested activists. Communicating efficiently. in search of temporary work. In the first place to help people energetic, light them the green light at the end of the tunnel. Rely on the established officials in a quarter-century type of confidence that is not the sword of justice hanging over them, and a safe senior bureaucrat to receive compensation, it is not necessary. Option - ONF. President and regularly communicates with its interested activists. Communicating efficiently. in search of temporary work. In the first place to help people energetic, light them the green light at the end of the tunnel. Rely on the established officials in a quarter-century type of confidence that is not the sword of justice hanging over them, and a safe senior bureaucrat to receive compensation, it is not necessary. Option - ONF. President and regularly communicates with its interested activists. Communicating efficiently.

Academician AG Aghanbegyan testified that a year of economic recession because of unwise management requires a lot more time to revive the economy. Act on the opening segment should so have the strength to finish and would have left them for the next stage. We should not hope for great achievements. Miraculous transformations can be expected in the private sector. Here it is able to manifest itself in case. In general, the process of the case is insignificant role. Refuse to believe in luck, however, is unwise. It is believed that "lucky" those who are lucky. Successful alignment may induce through professional activity, nature, faith in a favorable outcome, and even in a higher justice. Faith that accompanies the mind, yet no one prevented in an effort to do good work. [1]

All interstate unions must be considered solely in the national interest, otherwise you lose. Economic Agreement - an international condition, which is really to try to use for their own promotion, both at the company and industry. However, it should be understood that, unless you manage to benefit from the terms of the contract you have, then it will have your competitors, proved to be more savvy. Not ruled out a compromise where the mutual profit and temporarily divided proportionally participate. The main thing to know - the agreement in any form of competition leaves the competitors, it gives competition civilized, limiting arbitrary action. For Chinese leaders said production. Over 2016 Chinese sewed about 14 billion pairs of shoes -. 2 pairs for each inhabitant of the Earth. Chinese leaders so at the meetings, at the signing of the protocols. Our accounts more difficult - from them in the absence of similar indicators are waiting for assurances of friendship and mutual assistance. Good neighborly and mutually beneficial relations is the only valid reality of the progressive movement. Everything else - the virtual reality.

2. Bet on the full support light industry, like most areas of investment of public funds (financial, legal, political, and humanitarian), contains a risk, but within acceptable values. History checked and Russia as an independent state, and in the USSR in the ability to create a variety of quality goods in demand in sufficient quantity. Strengths of the domestic products of light industry: quality material, hygienic, ergonomic compliance with national and climatic conditions, variety of assortment. In the 1980s, with the development of co-operation have been positive developments in relation to the design. Clothing and shoes, since 1930, made available to all groups of the population.

In Russia it is possible to produce almost all kinds of materials needed for the light industry. Production of certain types of raw materials limited by volume, in principle, governed by scientific and technical progress. The development of science and technology complement the natural materials artificial synthetic. The country has developed scientific schools in the framework of agricultural production and light industry, the system of specialized vocational training was created. Personnel are trained in schools, colleges, high schools, some schools disappeared in the course of democratic reforms, but 


\begin{tabular}{|c|c|c|c|c|c|c|}
\hline \multirow{4}{*}{ Impact Factor: } & ISRA (India) & $=3.117$ & SIS (USA) & $=0.912$ & ICV (Poland) & $=6.630$ \\
\hline & ISI (Dubai, UAE & $=0.829$ & РИНЦ (Russia & $=0.156$ & PIF (India) & $=1.940$ \\
\hline & GIF (Australia) & $=0.564$ & ESJI (KZ) & $=8.716$ & IBI (India) & $=4.260$ \\
\hline & JIF & $=1.500$ & SJIF (Morocce & $=5.667$ & OAJI (USA) & $=0.350$ \\
\hline
\end{tabular}

the experience was training. It is not difficult to revive. Preserved industrial centers and enterprises. Precisely in those areas where a high percentage of the unemployed. The revival of the enterprises of light industry will lead to increased social and cultural environment and regional traditions, faith in the future the population. Return of social optimism in people.

In favor of focus to develop the production of goods required to meet the physiological needs of man, and are the size of the consumer market. They guarantee the stability of the production orders workload of the relevant goods.

3. There is still a high creative potential of specialists. He is quite competitive. Local artists, designers, engineers, and organizers have a high international rating. Often they are bigger and better known abroad than in his native country. Like all creative minded people they are seeking to diversify production development, taking into account the specifics of the market, aware of the importance of monitoring the interest and the mass market opportunities. We've gone from state regulation of the quantity, quality, price of products, than quickly took advantage of random people in the industry. Those who privatized enterprises, understand it as a way to improve personal incomes and sought to squeeze the maximum margin guilty in the collapse of the industry no less than their "senior" partner was determined by the fate of reforms mediocre people to create an economy. The oligarchs and crony capitalism as historically developing phenomenon. It is a mistake to reject the socially positive sense of their existence. One thing to financiers tycoons, media magnates, oligarchs who made a fortune on speculation mediation wild carbon extraction of raw materials, the other - those who developed the real production with a substantial proportion of the value added, ie, I am thinking about the future.

After the "Gaidar Economic Forum" and the Congress of Industrialists (. 2016), the oligarch Oleg Deripaska spoke very politically mature "in 2019 - the last year, when the state is able to use the reserves to help the production, next year we should start to help the state." We are sure that the opinion of one of the most active and experienced local oligarchs its exclusive look at the interaction between the state and businesses.

To flee from Russia in calculating the future - the lot of those who are opposed to Russia, hiding in the "white fluffy fur" abstract democratic idea of the unity of the world with his greed. The West does not need them, there is demand for their finances - not as impressive by Western standards, both in the looting of the homeland, and "anti-Putin views."

Russian history is rich in examples of intelligent, patriotic economic policy, namely large owners, were ahead of the actions of the public administration, endowed with political responsibility for the professional development of production. It seems that those who are directly responsible for the financial and industrial policy by examining historical experience, waiting to push the production itself "locomotives" for the promotion of existing staff. G. Gref, Sberbank released in the heads of the said government sector, openly referred to "the Gaidar Forum" told about the need for an active government policy planning for overcoming the crisis in the economy, finance investment in real production, control the use of state loans by banks. Frightened by the "wrong" - not cyclical crisis, banks do not want to risk even a "short" loans in the interests of production. They have a "roof" of speculators in the market and themselves became full speculators, floating financial turnover of state loans, leaving the manufacturing enterprises with no credit or assigning them to death calculation rules [1].

Light industry enterprises in a similar situation a little bit easier to operate. First, replacement of the equipment is not as costly affair. For example: the basic equipment with modern equipment Physical Laboratory costs $\$ 5$ million.. Secondly, you can do "short" money that the joint interests of the financier and producer. But at the same time, light industry enterprises more dependent on rapidly changing market conditions, therefore, need to be able to spin quickly, to be able to use centrifugal forces - to diversify production. "Diversification" - the versatile word. In dictionaries allocate 4-5 values. In the context of our study are relevant three: "Diversification of production" as the spread of economic activities to new areas, the branching of production, diversification of products; kind of marketing strategy,

Diversification is currently "working" in the "most favored nation" mode, of course, if you have a creative approach, weighted risks and skillfully the aligned monitoring. We have in mind to begin the transition to the development of mass production from the first type in the second - «lean production», which can be translated as "gentle" or "prudent production." This type of production fundamentally changes the very purpose of the production process. In this case, the traditional task of manufacturing a large number of similar products to meet the requirements of normative documents, of which the consumer should choose the most suitable for him, replaced by the problem of manufacturing such a product is what you need to present to the consumer and it is in the required amount and at a certain time.

A new type of mass production shifts planning optimization studies to study the peculiarities of the market demand as the total expression of individually different wishes. The market is personified as a function of a large number of parameters involved, which requires strengthening the diversification of production. Changing nature of the market, and employers are required for this transformation adequately and to respond quickly. 


\begin{tabular}{|c|c|c|c|c|c|c|}
\hline \multirow{4}{*}{ Impact Factor: } & ISRA (India) & $=3.117$ & SIS (USA) & $=0.912$ & ICV (Poland) & $=6.630$ \\
\hline & ISI (Dubai, UAI & $=0.829$ & РИНЦ (Russia & $=0.156$ & PIF (India) & $=1.940$ \\
\hline & GIF (Australia) & $=0.564$ & ESJI (KZ) & $=8.716$ & IBI (India) & $=4.260$ \\
\hline & JIF & $=1.500$ & SJIF (Morocco & $=5.667$ & OAJI (USA) & $=0.350$ \\
\hline
\end{tabular}

To change the paradigm of integrating the policies of the organization and management of production, to carry out its restructuring is not enough, but a serious modification in the planning activities of the enterprises have long needed. And it has begun, it may be as long as in the minds of producers and owners, but it is a natural introduction to the practice. mosaic study of market demand complicated the search for new markets. The desire to capture the market in 2016 is unreasonable, as well as a dream to overtake China, we catch up with him, and only in a dream possible. Fortunately, you can overtake in many ways. The most primitive variant - to do something bigger, more promising - to get ahead, to squeeze into the structure of the market, where its density is not as great. The general director of the Novosibirsk enterprise "Clothing Factory" N. Treshchev sure that really squeeze into the ranks of the products' quality sewn "in a sufficiently rich fabrics, interesting design. In the 1990s, Russia had stopped the "Bush legs", and it seemed nothing could displace them from the market. At the present time they do not even remember. Our Ptitseprom won. Why should we fear the intervention of Chinese consumer goods? Looking for protectionist measures at the WTO, the SCO, but in principle they are not the crux of the matter. The movement of productive independence from external factors. Sustainable development - a consequence of self-propulsion. If you do not promote the development of existing conditions, it is necessary to look for reserves in the process, "removing" the negative effects of external circumstances. Our Ptitseprom won. Why should we fear the intervention of Chinese consumer goods? Looking for protectionist measures at the WTO, the $\mathrm{SCO}$, but in principle they are not the crux of the matter. The movement of productive independence from external factors. Sustainable development - a consequence of self-propulsion. If you do not promote the development of existing conditions, it is necessary to look for reserves in the process, "removing" the negative effects of external circumstances. Our Ptitseprom won. Why should we fear the intervention of Chinese consumer goods? Looking for protectionist measures at the WTO, the SCO, but in principle they are not the crux of the matter. The movement of productive independence from external factors. Sustainable development - a consequence of selfpropulsion. If you do not promote the development of existing conditions, it is necessary to look for reserves in the process, "removing" the negative effects of external circumstances.

The state is obliged to make a change in the decline in the prestige of professions related to light industry, to create the attraction for those who have decided to devote themselves to this interesting case. The owners are looking for reserves to raise salaries. She VAT in 2018 did not exceed 14 thousand. Rubles, which is half the salary of the average for the region.
Director of footwear enterprises Titov sees output in the transition to automated production systems. Companies in the past year for the acquisition of the Italian and Taiwanese equipment costs $350 \mathrm{mln}$. Rubles, which made it possible to attract qualified professionals to carry out training of the core staff and to raise the salary to an average of 28 thousand. Rub. Forecast of development of production Titov links with increased manufacturing of shoes mainstream segment. In favor of the forecast A. Titov work and reducing the presence in the domestic market of Turkish production. It is necessary to take into account the fact that China's growth will inevitably lead to an increase in wage costs. It will emphasize the relevance of logistics calculations. As a result, the Chinese will lose economic attractiveness, and with them it will be possible to compete in the segment, interested Titov. The Russian industrialists there is such a trump card, as its raw materials of natural origin. We hope that the promised investment in agricultural production will reach the farms and fields. The market for light industry grows at the expense of social and cultural progress, in particular through the development of professional sports, the increase demand for those who choose the sport as a way to a healthy lifestyle. At the end of 2015, "Sport Express" newspaper published an interview with the chairman of the Russian Outdoor Group A. Grebtsova. "The market for outdoor-goods serves climbing, hiking, extreme sports, special forces, rescue teams, service and polar forces. This direction, which require a heavy-duty, freezeproof, waterproof equipment that meets the new international safety and comfort standards. " A. Rowing reported interesting details, in particular, he compared the technological base of production of quality products in the Russian Federation, Europe and Asia. We are "somewhat behind", according to his estimate, from the Asian potential, but with Europe "Just can compete ... in Russia there are about 30 (!) Companies that are good at sewing." After the ban of imports for state procurement and defense contracts share materials from member countries of the Customs Union, delivered to law enforcement agencies of the country increased from $30 \%$ in 2011 to $83 \%$ in 2018 . In 2019 the trend of increasing the share of countries in the production of materials KPES used for the production of ware property should be around $85-90 \%$. Reversal of state order in the direction of domestic production opens possibilities for allied chemical industry (raw yarn, fittings, membranes, insulation). Grow production fabric, tailoring, it will pull the development of equipment. A. Grebnev believes that in order to consolidate the results achieved it is important to: [2] In 2019 the trend of increasing the share of countries in the production of materials KPES used for the production of ware property should be around $85-90 \%$. Reversal of state order in the direction of domestic production opens possibilities for allied chemical industry (raw 


\begin{tabular}{|c|c|c|c|c|c|c|}
\hline \multirow{4}{*}{ Impact Factor: } & ISRA (India) & $=3.117$ & SIS (USA) & $=0.912$ & ICV (Poland) & $=6.630$ \\
\hline & ISI (Dubai, UAI & $=0.829$ & РИНЦ (Russia & $=0.156$ & PIF (India) & $=1.940$ \\
\hline & GIF (Australia) & $=0.564$ & ESJI (KZ) & $=8.716$ & IBI (India) & $=4.260$ \\
\hline & JIF & $=1.500$ & SJIF (Morocco & $=5.667$ & OAJI (USA) & $=0.350$ \\
\hline
\end{tabular}

yarn, fittings, membranes, insulation). Grow production fabric, tailoring, it will pull the development of equipment. A. Grebnev believes that in order to consolidate the results achieved it is important to: [2] In 2019 the trend of increasing the share of countries in the production of materials KPES used for the production of ware property should be around $85-90 \%$. Reversal of state order in the direction of domestic production opens possibilities for allied chemical industry (raw yarn, fittings, membranes, insulation). Grow production fabric, tailoring, it will pull the development of equipment. A. Grebnev believes that in order to consolidate the results achieved it is important to: [2]

- make clear the importance of large retail chains purchase and placement of goods produced in Russia, of course, in view of their good quality;

- place the first orders for the production of those "who have stood up and knows how to sew." They have proved their worth;

- assist companies to obtain a European certification materials, otherwise they are not interested in foreign companies, and the goods produced in our country, does not get to the West;

- to actively support the company's collective stands at international exhibitions;

- represent such enterprises subsidies on loans for the purchase of raw materials. These loans Ratio of total lending should be from 50 to $85 \%$;

- to liberate the modern import equipment from import duties and VAT. Equipment used in sewing shops, $90 \%$ of imports;

- implement preferential leasing.

As you can see the program A. Grebneva organizes basic and the primary steps in the direction of the light industry to ensure that the return to its former value. However, Heraclitus was right in saying that you can not step twice into the same river. The rise of light industry should be made to the new technological, economic and legal framework.

4. The reforms of the 1990s opened the "floodgates" for the flood of Chinese consumer goods. Purchasing power somehow got out before its price. Shuttles trampled on the border with its eastern neighbor entire prospectus, and in fact with them and through them to form cultural perception of the product. First they bought from despair, then, because it is cheap. And instilled a primitive flavor, bordering on bad taste. In modern times, you need to thoroughly work on the culture of consumer demand - to educate the customer. We have repeatedly emphasized in our publications, understanding that the quality of the natural and artificial phenomena is not the same. Consumer goods are made by man and for man. It alienated human essence, including the socio-cultural status of the individual. Consequently, and an understanding of quality should include a subjective perception of a product's performance through the senses and reflection. quality perception should not be allowed to "drift" to give a sensual element or simplistic thinking. It is important to learn not only the art of modern design, high-quality stitching shoes, clothes, you need to help the consumer to understand all this, send it to the aesthetic and hygienic presentation, make him empathize, to feel the satisfaction of the purchased goods.

Wise Buddha is laid in the eightfold path four key steps:

- correct understanding; making the right decisions;

- finding the right words and, finally,

- right action,

- aimed at implementing the right solutions.

The fate of the light industry now depends on what will be the final step. His performance functions of government. Political paradigm is extremely simple - we should not compete with anyone in the fight for the world market, especially the Chinese. The Chinese rightly want to put on and to put the whole world. fifth of the world's population lives in China. Our task is quite different. We need to make sure that the Chinese are not shoes and wore us. Translate purchasing demand for its own Russian production, interest in goods produced in the country. The task such, we are quite capable, as they say manufacturers. And the government need to do consistently and in a timely manner their direct work, that is, to think, to make decisions, bring everything to the result, team work and, most importantly, respect each other in this team.

The results of the survey on the impact of marketing communications on the promotion of products of light industry in the markets of SFD and North Caucasus Federal District with the participation of students, teachers and specialists and the evaluation of competence of survey participants using the coefficient of concordance W showed the same feature, characteristic of a survey of other problems, such as the impact of competitive potential on the competitiveness of and demand for products, the role of the chipping of fur products to improve filling market demand this produ ktsiey, demand and quality, revealed the relationship competitiveness of enterprises and the competitiveness of products for the formation of a stable demand for manufactured by domestic enterprises of light industry products for consumers SFD and North Caucasus Federal District and to provide them with a stable economic situation with a guarantee against bankruptcy regions. In addition, it was carried out a survey to assess the significance of master's training to fill the domestic enterprises of light industry by highly qualified specialists, the need for which is so acute that borders on catastrophe to ensure the industry such specialists capable of against the background of advanced innovative technology solutions to form the innovative production, guaranteeing businesses 


\begin{tabular}{|c|c|c|c|c|c|c|}
\hline \multirow{4}{*}{ Impact Factor: } & ISRA (India) & $=3.117$ & SIS (USA) & $=0.912$ & ICV (Poland) & $=6.630$ \\
\hline & ISI (Dubai, UAI & $=0.829$ & РИНЦ (Russia & $=0.156$ & PIF (India) & $=1.940$ \\
\hline & GIF (Australia) & $=0.564$ & ESJI (KZ) & $=8.716$ & IBI (India) & $=4.260$ \\
\hline & JIF & $=1.500$ & SJIF (Morocco & $=5.667$ & OAJI (USA) & $=0.350$ \\
\hline
\end{tabular}

producing import-substituting products, create a town-forming enterprises in small and medium-sized cities of the Russian Federation, providing the population of these cities not only in the workplace, which in itself is vital to ensure that the population of these cities social protection, reduction of unemployment and a decrease in population explosions that can destroy the integrity of the country. In addition, the elimination of the deficit on highly qualified professionals, to provide producers with the justification for such productions for the accumulation of domestic market demand products, including those for children, which is a significant deficit today. Naturally, for the success of the light industry enterprises need to develop domestic production of components, because the number of products for more than a hundred titles,

Analyzing the results of the survey with the participation of all respondents traced the main concern of the survey participants - uncertainty in the interest of municipal, regional and federal branches of government to provide assistance to solve vital problems typical for light industry enterprises, namely:

- low salary;

- low profitability of manufactured products;

- high staff turnover;

- morally and physically obsolete equipment, ie technical and technological backwardness of light industry from foreign countries, characterized by high consumption of materials, energy content, and laborintensive production;

- a low level of innovative solutions in the industry, provoking weak competitiveness of domestic goods, in the low share of "know-how" and innovative products in the volume of sales in the Russian and global markets;

- a high share of imports that caused the strengthening of the strategic and marketable government dependency on foreign countries, although it is no secret that the competitiveness achieved through the modernization of production processes. The new equipment allows to produce new types of products, but often the equipment we have just imported. We already bought it more than our foreign competitors, moreover, are forced to keep still and backup equipment, as if some unit of broken equipment or fails, it could trigger a stop the whole process, and reduce the output volume, which, of course, have a negative impact on the performance of the enterprise;

- the absence of a civilized market of consumer goods, in terms of increased competition in the domestic market between Russian and foreign producers;

- social and personnel problem, which manifests itself in shortage of highly-qualified professionals, managers, main and auxiliary workers in all production processes.

They are connected both with the industry activity, and with the ongoing institutional reforms and changes in the national economy, in the area of legislative and foreign economic policy of the country, as well as changes in the global economy.

Mass domestic manufacturer hardly interested in the quality of the theory. It is not relevant to him. If, however, someone accidentally stumble on our discussion, then, likely to smile their naivety. Try using the theory to rebuild the Russian market, to give it a civilized form - classical quixotic. First, you need to organize a market space through political will, legislative initiatives and effective, rather than the sham, control legalized the procedure to return to the market of goods manufacturer, removing significant number of intermediaries - speculators.

This manufacturer is not interested in speculative transactions. Him for sustainable development requires a consumer who, by the way, in turn, do not mind to have some specific and affordable producer within the moral - legal relations.

national esteem brought history and the current reality. At school you can learn from the best history textbook, but apart from school lessons of history have a current life, more impressive historical narratives. In the East, saying: "How many times do not repeat paste, the mouth is not sweet." The theory has always been considered the best practical guidance, however, in normalized circumstances activities. Heading into the illegal and semi-legal status, manufacturer, and alienated from the quality, of course, on the quality of the theory. Next there is a substitution of quality pseudo quality and increasing costs of advertising props. The quality of human activity reflects a complex of its characteristics, which to the greatest extent to the ideal conception of success. [one]

The object of the control is human activity in the totality of its factors, characteristics and features. But man, any activity is a set of actions aimed at solving any problem, allowing to achieve the goal. Therefore, we can talk about the quality of management as the management of those characteristics of human activities that make this such an activity, which is necessary for reliable and real achievement.

any process management in the end results in an impact on some of their characteristics: Performance, reliability, timeliness, design, efficiency, etc. The complex of these characteristics reflect the quality of work. That is why we can talk about the quality of management as a special approach.

In management there is a goal and the means to achieve it. And between these two factors are set welldefined relationship. This relationship specificity, interdependence, direct interaction, adjustment, flexibility, adjustment.

In most cases, our domestic governance is considered nothing more than a means to an end. If we 


\begin{tabular}{|c|c|c|c|c|c|c|}
\hline \multirow{4}{*}{ Impact Factor: } & ISRA (India) & $=3.117$ & SIS (USA) & $=0.912$ & ICV (Poland) & $=6.630$ \\
\hline & ISI (Dubai, UAE & $=0.829$ & РИНЦ (Russia & $=0.156$ & PIF (India) & $=1.940$ \\
\hline & GIF (Australia) & $=0.564$ & ESJI (KZ) & $=8.716$ & IBI (India) & $=4.260$ \\
\hline & JIF & $=1.500$ & SJIF (Morocce & $=5.667$ & OAJI (USA) & $=0.350$ \\
\hline
\end{tabular}

consider that goal, as a rule, inadequate definition, and the means of achieving them have the same property. Quality control is present as a general description of the product, achieved through regulations, standards, technical control.

World experience of management indicates a change in the quality status of the system and management processes. The strategic plans of many companies quality is regarded as the main goal of management that defines and profits and image, and stability, and confidence in the competition, and the prospect of development. This is evidenced by at least the experience of Japan.

Modern management requires the setting of quality problems as a control target, and the achievement of this goal requires a well-defined resources. The management of quality is very important realization that quality can not be achieved without taking into account all its components, without the organization of cooperation in the quality management system criteria. Many previously established quality management systems, the main role was played by the characteristics of the product, the properties of the produced object, rather than a complex of certain characteristics that reflect the social and economic process of functioning and development of production, the quality of the socioeconomic system in general.

Product quality is the result of many factors -. The quality of personnel, quality of the organization of production, the quality of engineering and technology, quality management, design development, etc. All this seems obvious, however, in actual practice, quality management does not become even a special type of control.

The problem of quality in management should have the status of the objectives and management of the subject. It is difficult, but necessary, because we have a different approach to the definition of the content addressed in the management of problems, evaluate them very complex factors. The quality of products can be seen, evaluate, understand. But the quality of the company's activity, giving good product quality, identify and difficult to assess, especially to evaluate the potential of quality. Not everything can be measured by the final result, not all are equally explicitly includes the final result. Much as it falls in the course of its production, formulation, it is transformed into other properties. That is why the quality of the products and the quality of activities it's not the same, but the latter is much more important to control the analysis of its organization, to set goals and management guidelines, the choice of means and methods of management.

Here here and there and it intensifies a real need for a systematic approach, not just in his declaration. In practice, in the formulation of the problem, in the disclosure of its content, we often exclude the very possibility of a systematic approach to problem solving.

We should not think that the quality is determined only by the technological content, there are factors that go beyond technology. These are factors working culture, aesthetics, production, market conditions, social consciousness, production infrastructure and so forth.

The systems approach methodologically requires to take into account not only the fact that there is available in this product, as a finished product, but also the fact that there was in the process of its production or formation. In many cases, it was difficult and time-consuming process in which something disappears, turns into something else, something to change the status. But nothing goes unnoticed, and everything stays in one way or another as. Especially valuable and quality notion that it focuses on a systematic approach, if considered as a management objective that it requires to take into account the factors of procedure or structure, existence and development of the factors for a particular environment, human interests, values, social life and so on.

Today, not only the state standards and quality requirements necessary for quality management. They may reflect a minimum level of quality, which is to defend the state. All state requirements for quality - is the administrative system of quality management. No standards and state requirements will not be able to keep up with the changing human interests, market competition process, the change in the system of values and way of life. And it is they who determine the quality and understanding of the need for flexible, social and economic quality control. [2]

As a necessary criteria, reflecting the dynamics of socio-economic processes. Quality should be determined by market situation characterized by the processes of supply and demand dynamics, needs and values. After all, only through market mechanisms of supply and demand, competition, pricing, and other processes can reveal the true quality of the product, to show that it is necessary to take into account its characteristics. State requirements if they are to be able to guarantee a minimum of quality, which is constructed by the system of protection of the consumer from the very low-quality products. This quality dynamics can only be understood in economic terms of supply and demand, competition, pricing, product functionality, its effect on lifestyle and role in changing the lifestyle of the person.

Quality - is not only a set of product features, and it is the initiative and activity of manufacturers in achieving these properties, search for and achieve their specific combinations.

Quality - a concept of socio-economic type, it is not a static system properties, it's a man's attitude to his work, to society, to the management. 


\begin{tabular}{|c|c|c|c|c|c|c|}
\hline \multirow{4}{*}{ Impact Factor: } & ISRA (India) & $=3.117$ & SIS (USA) & $=0.912$ & ICV (Poland) & $=6.630$ \\
\hline & ISI (Dubai, UAI & $=0.829$ & РИНЦ (Russia & $=0.156$ & PIF (India) & $=1.940$ \\
\hline & GIF (Australia) & $=0.564$ & ESJI (KZ) & $=8.716$ & IBI (India) & $=4.260$ \\
\hline & JIF & $=1.500$ & SJIF (Morocco & $=5.667$ & OAJI (USA) & $=0.350$ \\
\hline
\end{tabular}

In terms of quality mark assignments, we have always been in a state of growth. But the true dynamics of the quality we felt in spite of this indicator. It is natural to conclude that - or underestimated the criteria, or just incorrectly compiled and used these indicators. Quality mark did not show the true quality. This can be seen even on the export of products. The volume of products with the quality we have grown, and demand for our products in the world market declined due to the poor quality of its non-compliance with international standards.

Now there are processes of structural adjustment of our production, and it is important to lay the control system fundamentally new quality management framework, to focus on the production of quality management as the goal, and the foundation of successful operation of production. Quality - this type of development, this new approach to the regulation of product life cycles, the creation of new types of products, the assessment of obsolescence and physical deterioration, taking into account the principle of universality.

Quality management requires appropriate that purpose information support system. Relying solely on the meager data of domestic accountability, can not sometimes make a true picture of the quality of the state, especially to find the reasons for his change, or to assess the processes of formation. But the main thing is to manage the quality of the sources and trends change.

The quality control problem is reduced traditional representation mainly to the quality control problem. It is a sign and a factor administrative approach to quality management. But the experience, both domestic and foreign, show that the main quality of a comprehensive quality motivating factors of management, in which the leading role is played not control, it can be minimized, and the image of the productive worker, which are connected and function, and goals, and means of self-affirmation, and interests, and attitudes toward the company, and communication skills, and socio-economic activities of the atmosphere. Management should be focused precisely on the image of the activity corresponding to a certain type of quality activities.

This eventually gives the product quality and without a hard type of administrative control, and control of both the analytical evaluation system.

The "mark of quality" of the market economy the price of the product, its reputation, the demand, the company's image, which generally produce lowquality products can not.

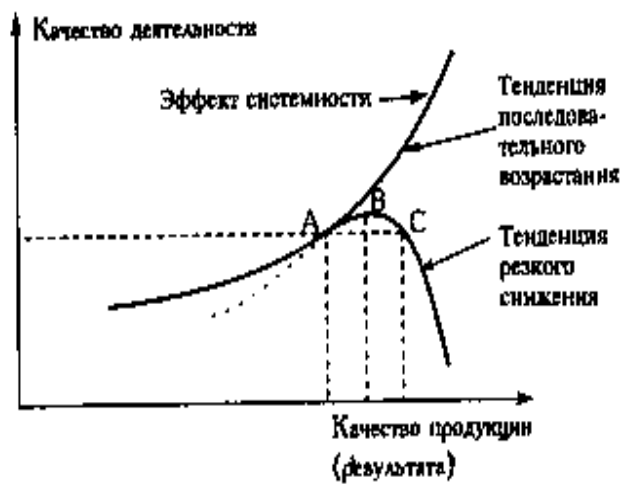

\section{$\mathrm{A} \rightarrow$ точка необходиного переключения приоритет. \\ В - точка упущенных возможкостей в росте качества продукции \\ C - точпа тендеңпии на снижение кацества}

Figure 1. Changing priorities and management role in the achievement of quality, seven steps into the future 


\begin{tabular}{|c|c|c|c|c|c|c|}
\hline \multirow{4}{*}{ Impact Factor: } & ISRA (India) & $=3.117$ & SIS (USA) & $=0.912$ & ICV (Poland) & $=6.630$ \\
\hline & ISI (Dubai, UAI & $=0.829$ & РИНЦ (Russia & $=0.156$ & PIF (India) & $=1.940$ \\
\hline & GIF (Australia) & $=0.564$ & ESJI (KZ) & $=8.716$ & IBI (India) & $=4.260$ \\
\hline & JIF & $=1.500$ & SJIF (Morocce & $=5.667$ & OAJI (USA) & $=0.350$ \\
\hline
\end{tabular}

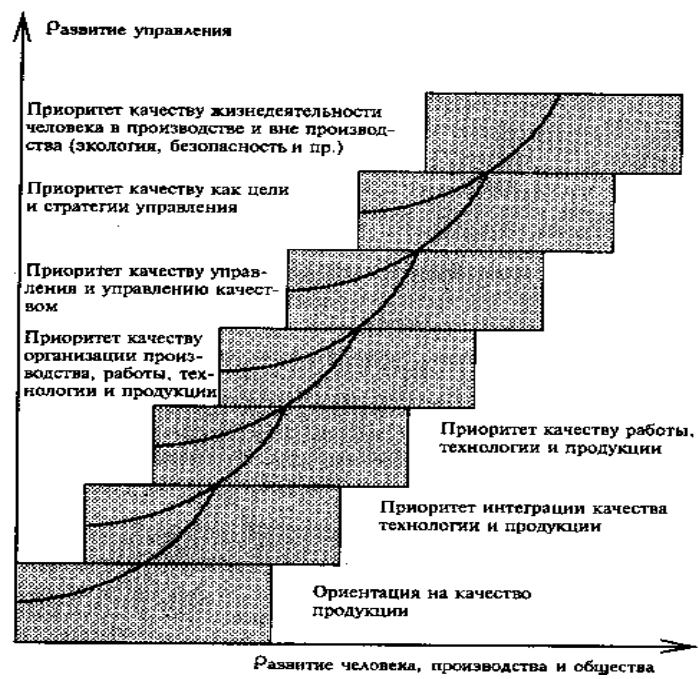

Figure 2 - The quality of work and product quality: the interdependence of tendencies

Achieving quality requires a certain cost. The value of the quality of the cost - the most important characteristic that reflects the quality of management. But the cost of quality is not yet characterize the potential to achieve quality. Costs can be very high, but lower quality because the costs not always have immediate and direct impact. They sometimes serve only the sequence of formation of quality building, such as the qualification of the cost of employees, production infrastructure. [2]

Therefore, great importance to quality management is the formation of the quality of building, which includes cultural activities, social and psychological atmosphere, qualifications and education of employees, technology, technical equipment, the type of organization.

Quality does suggest serious costs, but it ensures a stable market position. Working on the quality, the manufacturer creates confidence in its future and national. Properly structured understanding of the quality guarantee term, even in the conditions of domestic sex market].

We will try to introduce in order to formulate a theory practically significant fundamental positions:

Quality can not be reduced to the amount of goods being important for the properties; it is - a kind of combination, which was built on the basis of generally two features - a more general and more specific. For example. Shoes - "clothes for the feet," the hat - "for the head dress" scarf - "clothes for the nose and neck", etc. Consequently, the central attention should be paid to them.

Quality allows changes that do not lead to loss of quality, but reduce or increase its customer value; quality - quality set of states satisfying in varying degrees backbone characteristics. "Backlash" quality allows you to maneuver in the process of creating a product with a given quality, depending on the specific features of producer and consumer.
Quality not quantity is there - they are dialectical opposites, their opposition is only valid within the unity, which implies that by creating quality, it is necessary to lay in the qualitative characteristics of quantitative expressions in respect of certain properties of the product, and the number of commodity products. AK Savrasov, finding themselves in a difficult situation, made a few copies of his famous painting "The Rooks Have Arrived". As a rule, author's copies have a high level of skill and are well paid. And paid to the artist. When asked P. Tretyakov: he would buy a copy of the artist's paintings, AK Savrasov, happen that the original? The answer turned out to be P. Tretyakov forecast for categorical - no! Quality requires not only skill, but also inspiration. Inspiration replays burns.

The quality and quantity of links the measure, which is most often overlooked. Meanwhile, the defining quality, you need to think simultaneously about its dimension, and from the standpoint of the market conjectures, and in terms of quality-signs themselves. "Quality" is specified in the idea of "quality." "Quality" - a concept that reflects the image of the product lineup, "goodness" - determines the quantitative limits of reality and the quality of intelligence (physical and moral goods status).

The quality and presentation of the quality related to the phenomenon of stability, however, the time change and. Initially identified quality with value. quality criteria were the subject of the usefulness and value of the relationship. With the development of consciousness and the practical possibilities of developed base of comparison and choice. Quality is relatively segregated from quantity. Committed differentiation of utility, is reinterpreted as part of quantitative traits. Evolution of understanding of quality is directly due to the embodiment of creativity in business. The discrepancy in the intensity of advancing individual skills, interests of those who are called to clear the way of talent and mass 


\begin{tabular}{|c|c|c|c|c|c|c|}
\hline \multirow{4}{*}{ Impact Factor: } & ISRA (India) & $=3.117$ & SIS (USA) & $=0.912$ & ICV (Poland) & $=6.630$ \\
\hline & ISI (Dubai, UAI & $=0.829$ & РИНЦ (Russia & $=0.156$ & PIF (India) & $=1.940$ \\
\hline & GIF (Australia) & $=0.564$ & ESJI (KZ) & $=8.716$ & IBI (India) & $=4.260$ \\
\hline & JIF & $=1.500$ & SJIF (Morocce & $=5.667$ & OAJI (USA) & $=0.350$ \\
\hline
\end{tabular}

consciousness complicates the understanding of quality and quality management process. Of particular importance is the quality of interpretation of concreteness, in particular, its basic feature such as objectivity. General theory of being built on the basis of natural history - an outline of its inherent nature and the historical pattern created man. In the natural environment, all signs, including synthetic such as quality - products of spontaneous movement. In society, every phenomenon passes through activities includes in its quality of mental and physical labor of man. Determining the quality of the phenomena created by human activities, it is impossible without the social and cultural specificity. In this connection, the updated two questions: what is the status and the extent to which consciousness is part of what is traditionally called the quality of things (with the clarity of the services more)? General theory of being built on the basis of natural history - an outline of its inherent nature and the historical pattern created man. In the natural environment, all signs, including synthetic such as quality - products of spontaneous movement. In society, every phenomenon passes through activities includes in its quality of mental and physical labor of man. Determining the quality of the phenomena created by human activities, it is impossible without the social and cultural specificity. In this connection, the updated two questions: what is the status and the extent to which consciousness is part of what is traditionally called the quality of things (with the clarity of the services more)? General theory of being built on the basis of natural history - an outline of its inherent nature and the historical pattern created man. In the natural environment, all signs, including synthetic such as quality - products of spontaneous movement. In society, every phenomenon passes through activities includes in its quality of mental and physical labor of man. Determining the quality of the phenomena created by human activities, it is impossible without the social and cultural specificity. In this connection, the updated two questions: what is the status and the extent to which consciousness is part of what is traditionally called the quality of things (with the clarity of the services more)? In society, every phenomenon passes through activities includes in its quality of mental and physical labor of man. Determining the quality of the phenomena created by human activities, it is impossible without the social and cultural specificity. In this connection, the updated two questions: what is the status and the extent to which consciousness is part of what is traditionally called the quality of things (with the clarity of the services more)? In society, every phenomenon passes through activities includes in its quality of mental and physical labor of man. Determining the quality of the phenomena created by human activities, it is impossible without the social and cultural specificity. In this connection, the updated two questions: what is the status and the extent to which consciousness is part of what is traditionally called the quality of things (with the clarity of the services more)?

The answers to both questions must be sought in the philosophical theory of alienation. The theory of alienation directly related to the quality of the theory does not. In her the keys to the methodology of the quality theory. From the above discussion it is clear arranged that the authors - not idealistic rather on the brink of pessimism and optimism. They perceive the modern critical approach pragmatic liberal marketeers to scientifically and philosophically grounded theory. Lite version of the theory, when torn from the general theory moiety is converted into the theory and customize a design for the sake of perverse market speculators, economic theorists and suppliers of highquality substitute for domestic counters satisfied. How long will the Russian economy will maintain this configuration, we (and only we) can not know, but the world economic development experience in different stages of economic relations shows that the transitional periods are, and eventually economic life comes to its normal state.

The trajectory of human creativity in the process of alienation that exists outside it, should the need to preserve and enable the ability to create. In contrast to the life of nature, the human being is not substantively. It is not self-sufficient and can take place only through interchange initially with nature, in consequence of a society through which human relations are built to each other and interact with nature. Tool that provides human being - work, higher quality of work is shown in operation.

Quality work, on the one hand, the index of quality of life (as it should be!), On the other - highquality work is embedded in the quality of what he translates. The quality of the "first" (natural) nature is formed itself as a set of objectively related natural signs, spontaneously. The quality of the "second" (reconstructed, adapted by man for their own interests) Nature Synthetic. It is a double helix formed by the natural attributes of a natural material (possibly - in people's attitudes, knowledge, expressed indirectly) and qualitative characteristics of human activity - knowledge, emotions, will, values, craftsmanship. As a result, quality of the product as opposed to the quality of the product embodies the personality.

Personality alienated as and because, in principle, the alienation of natural and does not inhibit a person. The negative consequence of the alienation caused by the disproportionate compensation for lost energy activities. Finding no quality goods, hidden marriage of production, fraudulent actions of the seller, the buyer is upset normal, primarily due to the poor quality of their own solutions. Other losses of the transaction often reimbursed. There is a feeling of imperfection own taste and knowledge. 


\begin{tabular}{|c|c|c|c|c|c|c|}
\hline \multirow{4}{*}{ Impact Factor: } & ISRA (India) & $=3.117$ & SIS (USA) & $=0.912$ & ICV (Poland) & $=6.630$ \\
\hline & ISI (Dubai, UAI & $=0.829$ & РИНЦ (Russia & $=0.156$ & PIF (India) & $=1.940$ \\
\hline & GIF (Australia) & $=0.564$ & ESJI (KZ) & $=8.716$ & IBI (India) & $=4.260$ \\
\hline & JIF & $=1.500$ & SJIF (Morocco & $=5.667$ & OAJI (USA) & $=0.350$ \\
\hline
\end{tabular}

The quality of everything that is created activities, including property activities, both practical and spiritual in objectified (a microscope or functional) terms. The conclusion of the need to shape and guide the development of mass consciousness the ability to quality assessment of goods: some experience in the Soviet era and has been shown to be effective, "circles", "school", "university", including those initiated by the TV and radio. Place the system of education the mass consumer, professional assistance in the development of a culture of quality selectivity, today the air clogged aggressive advertising, the quality of which is not controlled or control is not commensurate with the size of the fraud. Who should be the main educator? Manufacturer and he alone, because only it fully, according to the logic of formation of understanding, you should know what quality is. To undertake the production of goods, not having comprehended particular quality of this product, it is a professional failure in the market.

Release of the same product with sham quality pursued by the law, however, formally and ex post facto. On the last and hope pseudo suppliers of quality goods.

For objectivity's sake let's say: the true creators of quality products will be in our market outcasts until such time as peace officers are confident in their impunity for corruption. Nevertheless, it is necessary to go forward. History ugly, but still moving towards conservatism order manufacturing technology, but also in the period of municipal government severely tested the quality of products, as well as the ability of the candidate to the producers operated official position, approved by the authorities of the city or the country. Agricultural products controlled by the users themselves.

The Industrial Revolution has simplified the production process, has established the mass production conditions. It took adequate quality control measures. As the leveling of social architectonic and greater accessibility to the range of products, changing perceptions about the quality in the direction of its quality - quality components. At the same time formed the possibility of falsification of quality. Further and de facto and de jure, it remained just a step to the substitution of brand qualities. Going abroad action paves the way for legal violations and moral crisis, up to no limit.

On the way to a consensus arises seller, the subject of relations, which, in essence, to the quality of the goods is irrelevant, but it was he - a key figure in a market economy. We had all the necessary gain. $\mathrm{He}$ - a monopoly and as such dictates the terms of the relationship through the price and size of interest income. In Russia, for twenty years, not a single branded light industry, on the contrary, declare an array of retail brands. Trading numbers multiply, and consumers are assured that the production of goods unprofitable. The culture of the organization of trade replace the concept of "selling quality". Trade Culture measured range, price and physical availability of the product, high-quality advisory support, the lack of queues, the observance of hygiene, appearance and behavior of staff, servicing. "The quality of trade" is determined by proportionality of prices and quality of goods corresponding to the goods sold its certificate, demonstration of goods. Size seller profits must not exceed the manufacturer's profit. Both do not have to wait for increase in consumer activity only by increasing the wages of consumers, and create the most favored for the buyer (without entering into an agreement with another market predator - the banks). [2] and create favorable conditions for the buyer (without entering into an agreement with another market predator - the banks). [2] and create favorable conditions for the buyer (without entering into an agreement with another market predator - the banks). [2]

Only in Russia, and only liberals - marketeers every chance remember how bad it was to the people before the onset of true democracy - starved, went ragged lived is unknown where and how. Monitoring the quality of life - through the quality of consumption opportunities - is appropriate within the existing time. One criterion - increasing consumer basket and thereby it increases?

The size of the inflation - a necessary but not a sufficient indicator of the quality of life. The government took over the main reference point decline in inflation. Figure actually socio - economic significance, it testifies to the culture of the market and indirectly on the production status. Less of this index - the lack of quality in it. Quality of life is determined by the amount of consumption of products in terms of money. Qualitative composition remains constant and can only be of a qualitative as blurs quality. Quality shoes, clothing, cereals, fish, vegetables, fruit within the common name is very significantly different. Provision of quality manipulation is significant. The main thing to understand the quality, not the name, and the system characteristic of the product, reflecting the range,

The quality system is essential for a product's performance - it is commonplace and well known than actively use. Substituting properties or their consistency in product quality. Essential properties those that are not just inherent in the product, they are responsible for its functionality. These properties are usually disclosed in the "work" of the goods to the destination, they are hidden from the view of nonprofessional user. The "pure" market - the mediator and to the quality of products must not have interest. market problem in the theory of the organization of commodity production - organization of exchange between producer and consumer. Market development stimulates the production capacity in the interests of consumers within the infrastructure market status. 


\begin{tabular}{|c|c|c|c|c|c|c|}
\hline \multirow{4}{*}{ Impact Factor: } & ISRA (India) & $=3.117$ & SIS (USA) & $=0.912$ & ICV (Poland) & $=6.630$ \\
\hline & ISI (Dubai, UAI & $=0.829$ & РИНЦ (Russia & $=0.156$ & PIF (India) & $=1.940$ \\
\hline & GIF (Australia) & $=0.564$ & ESJI (KZ) & $=8.716$ & IBI (India) & $=4.260$ \\
\hline & JIF & $=1.500$ & SJIF (Morocco & $=5.667$ & OAJI (USA) & $=0.350$ \\
\hline
\end{tabular}

Monopolization of production has led to the accumulation of financial capital, autonomisation of the latter and control the market. As a result of the market intermediary has become a key subject, the indicator function - to show the demand for goods trying to replace the role of the organizer of economic activities in general, which distorts the economy system. [2]

Economy of commodity production have created the product production and the need for mass product. Systemically important factor here is the production of the commodity as a product required for consumption by others, ie the process of alienation of consumption. When the production of natural quality of the product is unlikely to have been an actual problem. The quality of "dissolved" in the conservative engineering and technology, the traditional range. I raised the question of a consumer when the fair had the opportunity to compare. The market, which has grown from fair gatherings, Executive status gradually enriched advertising business by taking control of the relationship of producer and consumer. levers - fiscal policy, direction - basic - two: the impact on the quantity and quality.

Product quality has gained importance in the production of commodities. It became clear that in understanding the present sensory quality and rational thinking (the latter in the form of calculation). The subjective factor is objectified and fetish. The objective properties of the goods market directly (using their own mechanisms) is not able to act, but on the objectification of subjective ideas might very well. Since manipulation quality first included in the function of the market, then it became an element of economic policy.

A robust and sound economic policy is designed to work on improving quality in two interrelated areas: technical and technological, unfinished rigid legal provision unit, and socio-cultural - to provide their full support to the establishment of the subjective perception of the quality of environment, to block the negative effects of advertising exposure for a long time and thoroughly become an attribute of market speculation quality importance for the buyer. Having a choice and paying capacity not serve as a basis unquestionable quality acquisition.

At current market price and the quality are separated even at auction, famous for organizational culture care. The buyer is converted to an expert and this grimace market is not as bad as it is illogical. Market forces the consumer to evolve as a person. From the layman with a purse we are not to be suckers, unwittingly tried to learn more about the subject of interest, raise their "purchasing skills." The term is not new, it is used by journalists, but for them it is the entrance, a verbal number and is not a new combination of words commonplaces for us, the most important concept without which modern quality theory has no systemic holistic view.

"Purchasing qualification" includes, along with the certain knowledge that help determine the location of the store, the range of prices for goods requires basic information about the manufacturer, product quality attributes, the market reputation of the manufacturer, the firm traditions, level of activity. Today, the consumer market naive buyer runs the risk of allowing beyond all measures being a victim not only of deception, but also their own carelessness, therefore, without any right to compensation.

The buyer in Russia is formally protected. In real life has to be guided by the well-known rule, "the rescue of drowning (" buy ") - the handiwork of drowning, read" Buy. " Increasing the "purchasing qualifying" if there is the desire for a mutually beneficial business state, activating the cultural heritage of national and patriotic mood of the mass consumer. Although there is a path other than the tried and tested under Mao in China - "the worse, the better."

Imported consumer goods - not Chinese - in 1980-90-ies. we had a great success! Impressive range of products, packaging, external features of the product. And in the end? After 10 years of Soviet brands manufacturer returns naturally in the absence of effective control, not the Soviet quality.

We are able to make high-quality products and it is able to regain "our" market. The issue is not even the price, the problem is a loss of control over the consumer (not only the consumer, according to the malfunction of missile technology, operation of aircraft, etc.) markets. We explain: we need economic policies. That's right, but it is a half-truth. If necessary, take. The authorities should have the power to not rated. It is time to understand that the economy has always been the policy of economic theory - political economy. [3]

Economic movement is self-movement, but it is not happening in a vacuum. Economy - the basis of a social movement. The Company provides the conditions for economic movement, and the state has the right to vigorously included in the economic selfmovement mechanisms and direct the development of the economy in the public interest.

It's amazing. When it comes to future technological progress, the futurologists of all stripes are moaning that the autonomy movement techniques lead to the domination of robots over a man, but it is better not to interfere with the development of economy. For someone better? Only one conclusion: not to break the self-movement of the economy in the interests of those who privatized the economy, and in whose service are "border guards", prohibiting the control of economic processes through policy.

None of convertible currencies not provide a quality trademark and the equivalent "free" movement of the currency continued under the guise of policy. 


\begin{tabular}{|c|c|c|c|c|c|c|}
\hline \multirow{4}{*}{ Impact Factor: } & ISRA (India) & $=3.117$ & SIS (USA) & $=0.912$ & ICV (Poland) & $=6.630$ \\
\hline & ISI (Dubai, UAE & $=0.829$ & РИНЦ (Russia & $=0.156$ & PIF (India) & $=1.940$ \\
\hline & GIF (Australia) & $=0.564$ & ESJI (KZ) & $=8.716$ & IBI (India) & $=4.260$ \\
\hline & JIF & $=1.500$ & SJIF (Morocce & $=5.667$ & OAJI (USA) & $=0.350$ \\
\hline
\end{tabular}

Financial self-movement creates opportunities for chaos in the consumer market. Sluggish state protects the legitimate interests of domestic producers, even when the product - the product of inter-ethnic integration. No political aggression, policy lags in the train instead of the economy, to keep ahead of its development on the basis of objective socio-economic trends. Politicians want to believe the explanation regarding the success of the WTO accession. Well, they were trading, creating a legal "safety cushion" for the domestic producers of consumer goods. The problem: they are concessions to the WTO is now seize?

The time for political action - not making - the most favorable. Datura nineties and zero like ebbed. Returned understanding of qualitative advantages of many Soviet products of light and food industry. There is a revival in consumer cooperatives that can stimulate the production of agricultural products in rural areas. Growing distrust of consumer imports, including by reason of its mass produced in China. Stabilize migration flows.

Tough assessment of the socio-economic situation and direct indication of the government's responsibility for the failure of presidential orders in 2018 in the Message V. Putin, associated with a determination to "tighten the screws" to the movement went on track. Explicit activation in international economic relations within the Customs Union, to restart strategic relationships with a focus on China, India, Iran, Latin America. Real possibility of full cooperation with Egypt, Syria and Iran in the same in the Middle East and African key states of the north - all of this unique international scope to restore the balance in the domestic market of consumer goods.

Domestic manufacturers need a "distinct" economic policies. By "distinctness" they understand: clarity, consistency, warranty tracking, which allows to cut diverse arbitrary administrative authorities and the "guardians" of order. Responsible for the quality of all. And those who produce and those who are called to ensure the rights of producers. The Customs Union is lit green light on the path of national products on the market Pact. Thus creating equilibrium real market competition, which assessed the natural rather than the quality of advertising. By the way, a great research topic - "as real and" advertising ", ie created by advertising.

No less important, and to analyze the quality problem in the coordinate system of the national mentality and ethnic integration. Integration consciously replaced by globalization, despite the evidence to the difference between these phenomena. Both tendencies are objective and are characteristic of the modern history.

Integration - interethnic interpenetration of the various activities of socio - economic, cultural and humanitarian scale. It can be inter-ethnic dimension, an example - "The Union State (Russia and Belarus); local - the Customs Union; Regional (SCO, EEC). Globalization refers to the global scale of the phenomenon. Among the global problems are those that have arisen as a consequence of the general, but not necessarily integration, processes, and require a consolidated solution.

Global problems, in contrast to the problems associated with the integration of potentially relevant, are of strategic significance. For example, how to protect life on Earth from large meteorites. When the time of the event postponed, but it goes beyond it relevant in importance, the resulting gap actively rush speculators, including financial oligarchs come from trying to remove uncertainty.

Quality due to globalization, but practically not so important. With the integration of the same quality is directly connected.

Consider the "quality of consumer goods" problem in a coordinate system the "national" and "inter-ethnic". First of all, we must find an answer to the question: can supersede national integration as a component?

Integration processes are built on common standards and metrological characteristics of the production, which corresponds to the objective reality. Technical progress is based on science, scientific knowledge are imperative in terms of normativity. However, the total not being self-sufficient. General requirements are implemented through special development, due to the particular circumstances of the action. In other words, as it were, standardized production of goods was not, still it will manifest the uniqueness of the production conditions.

Specific conditions - regional, national inherently present in the raw materials, climate, traditions, culture consciousness performers. And in all this the strength of production, determines the quality of the nuances of the product, creating a special interest in it of the consumer. Tea is grown in our time all over the world, but the uniqueness of the tea plantations in Sri Lanka, the national attitude to tea, Ceylon ensure the quality of the product leadership position. The same can be said of Kenyan coffee, Bulgarian and chilli, French cognac and champagne, Ukrainian lard, Bavarian and Dutch beers, Scottish whiskey, Russian linen, Egyptian cotton, silk, Chinese, Argentine leather, Greek olive oil and much more. Specific environment to be valued and to provide preferences of its reproduction. The basic treaties

Customs Union establishes inter-ethnic division of labor, which was built in the XX century, it contributes to the expression of the objective and subjective sides of the development of production, mutually enriching market, facilitating access to producers. But all this - the theory. The theory develops into reasonable practice not only because it is right. Practice theory does work, and to get the 


\begin{tabular}{|c|c|c|c|c|c|c|}
\hline \multirow{4}{*}{ Impact Factor: } & ISRA (India) & $=3.117$ & SIS (USA) & $=0.912$ & ICV (Poland) & $=6.630$ \\
\hline & ISI (Dubai, UAI & $=0.829$ & РИНЦ (Russia & $=0.156$ & PIF (India) & $=1.940$ \\
\hline & GIF (Australia) & $=0.564$ & ESJI (KZ) & $=8.716$ & IBI (India) & $=4.260$ \\
\hline & JIF & $=1.500$ & SJIF (Morocco & $=5.667$ & OAJI (USA) & $=0.350$ \\
\hline
\end{tabular}

desired result, the activities must be systematic and consistent.

Interest in the quality of the goods, in theory should begin not in production. Its initial position on a normalized market, more precisely at the meeting the producer and the buyer. Normal market - an indicator of quality of the goods. Demand pulls behind it the industrial chain. But it is not a spontaneous demand is abandoned to their fate buyers. Demand - a state of consciousness due to purchasing power, however, can not be reduced only to the amount of money, especially when strongly stimulated lending by banks. Demand, farmed out to intermediaries, lobbyists, speculators - a deadly disease to Russia's national producer. Demand should take control and shape, the buyer need to educate. Consumer education costs a lot. But it is worth it, if you look to the future.

Market liberalism corresponded to the flourishing economy of mass production of the first type, focused on the provision of free access and choice of products. Such production perceives the consumer as an abstract entity relations in the system "producer - the seller - the buyer." Seller play the role of an active mediator, but no more. He provides a cultural meeting place of the manufacturer to the consumer. The system also should be functionally active, suggesting no presence of its constituent components, and their participation. The perfection of the system is determined not aesthetics - sign design. It manifests itself in to maximize the capabilities of the system of relations which it stands. Perfection of system design - in the ultimate realization of the potential relationships, creates system.

Buyer is perfect as the subject of systematic interaction between its purchasing training. He is not the size of the payment ability. His participation is determined by the knowledge of the commodities and the economic situation. The consumer - not the application object actions of the seller and manufacturer. Consumer - market participant and in his (and others too) interest to be informed not advertising community and professional sources. Then counterfeit and "lohizm" cease to populate the market. Product quality begins in the mind. To impose an idea of the quality - bad for all legitimate economic actors. It should be brought up again by all: the manufacturer, the seller by the buyer and the institutions of civil society, if the state is passive.

The transition to mass production of the second type - "smart," "zealous" economy activates the system relations. The new light appears the market function. Together with the manufacturer, the seller is guided by the knowledge of consumer tastes. By the perfection of the system remains to make just one, but not a simple step - the whole world to undertake the formation of a consumer culture.

The current generation of the charge of the consumer attitude to life is not quite fair. Consumption - the ultimate goal of production. Problem - the lack of mass market, the trouble really sociocultural size of consumer culture. Another consequence of financing the cultural progress. Why one power after another, but the culture is still in power in the last stage of the political relevance? Time to realize that not only the science has become a direct productive force. Culture - is also a factor of development of production, and factor versatile and highly effective.

The market has a great potential to manipulate the products and prices in the absence of a clear thought-out and organized interaction in system of relations of producers and consumers. Liberal political economy focuses on the freedom of the market, without having to worry about the content of the concept of "freedom". Arbitrarily interfering in the responsibilities of the philosophy, the Liberals pretend to solve their problems, misleading professional thinking and social consciousness. Not all economists, theorists and practitioners versed in philosophical reflection. Using a similar position, growing its market liberals' notion of "freedom, trying to free the market from the necessity of submission to any of its terms. In fact, economic liberalism, proclaimed by Adam Smith in a specific format, transformed into a banal market anarchism. In countries, with strong democratic traditions, downloaded humanistic values and social responsibility, liberalism loses its political positions, but it does have a serious roof in the face of a thriving financial capital, fatliquoring by the market. We do not want to deprive the subject of the status of market development of cultural production. The market is no doubt it is, but to put the market in a number of common subjects of production, therefore, ignore the evidence of different treatment for the most important indicators of the development of production - the ability to increase the cost of labor. freedom of the market comparable to the freedom of the judges on the football field. Judges do not play, they provide the game under the current rules. They can slow down the pace of their actions, bring down the pressure, play along, but it all happens in the mind, under public supervision and professional and will be prosecuted in accordance with established procedure. Exchange market function objectifies his only important thing to remember about how to display objectivity. Material form of objectivity - is the technological objective of production, the physical reality of the goods - really is primary and is subject to the natural basis of social life; objectivity of production and economic relations, including the organization and division of labor "secondary" objectivity created with the creative participation of the subjects of labor - it's natural and historical objectivity. There are, apparently, a third, a transitional level of objectivity, indirectly controlled by the objective nature of the production. The market belongs to the third level. Hence, such a different reality of the market, Organizer Features manipulated quite arbitrarily within the market and in the interests of the market. Engels explained E. Dühring: "In a 


\begin{tabular}{|c|c|c|c|c|c|c|}
\hline \multirow{4}{*}{ Impact Factor: } & ISRA (India) & $=3.117$ & SIS (USA) & $=0.912$ & ICV (Poland) & $=6.630$ \\
\hline & ISI (Dubai, UAE & $=0.829$ & РИНЦ (Russia & $=0.156$ & PIF (India) & $=1.940$ \\
\hline & GIF (Australia) & $=0.564$ & ESJI (KZ) & $=8.716$ & IBI (India) & $=4.260$ \\
\hline & JIF & $=1.500$ & SJIF (Morocce & $=5.667$ & OAJI (USA) & $=0.350$ \\
\hline
\end{tabular}

society where commodity production is the dominant mode of production," the market has always been very well-known abroad ... among the "business people." Due to its specific reality "in transition" from being tightly regulated production according to the relativity of the terms of exchange of natural and historical specificity, the market actually combines adequate actions with specific properties, organizing of the last their infrastructure. They hide behind the "marketeers" "Iron argument" - market "barometer" of production conditions. In this position, all the actions that, according to the classification of Hegel, not valid are allowed as needed-conditioned. Quite logically Petzold, who saved Machism solipsism by introducing a " relationship 'potential member formula being. Petzold not personified the "potential member", but it was not difficult to understand that it must be something universal, standing on a subjective form of consciousness. Marketeers, absolutizing the situation of the market, more precisely, the exchange through the market, achieve control over production. Interest marketeers again reminds us of the power of money.

Of its objective position the market should not earn more than the manufacturers. Otherwise, production stops, and with it, and social progress. Now the situation is critical, and the first cause of the crisis is the policy of the financiers, the second - the market speculation. Prices of real goods in the market for a long time does not correspond to the value of their real production costs of delivery and sale. The problem is to liberals in one - form a mass. All the same, on the street XXI century. Therefore, the world politics in the sphere of modernization of education aimed at its "market" division. The vast majority of graduates doomed to be clerks, a small minority, mostly of their own, plus those who are especially talented pool of senior managers. It's not the name of the university, and in the interest of you, very rarely dependent on you. The heyday of the market and its infrastructure due to the birth of mass production. On the first level of mass production market has been the most regulated task to deploy the product in the implementation of the scale of production to reproduction was dynamic. Above all dominated by the need for the production of working capital, as the benefits of mass production is the ability to reduce costs, thereby reducing costs and increasing the competitiveness of goods. A key factor to make the time of sale of goods. "Time is money". Mass production has given rise to trade principle: the user can not find what he's looking! Universal Megastore offers almost the entire product range of the product in all its possible variety, including the price. Soon cleared that the lack of certainty associated with the high cost of raw materials, energy, maintenance of premises, a large number of unsold goods, especially the limited shelf time. Market with its function has not managed as planned. Was an important event, it has not received the deserved estimation may not want to lower the reputation of the market rating. Production workers "went to the people" - to study the demand in view of social stratification. Case is troublesome, reaching definitions are not as accurate as we would like, but even on a provisional level, it serves as a basis for production planning orientation. [3] has not received the deserved estimation may not want to lower the reputation of the market rating. Production workers "went to the people" - to study the demand in view of social stratification. Case is troublesome, reaching definitions are not as accurate as we would like, but even on a provisional level, it serves as a basis for production planning orientation. [3] has not received the deserved estimation may not want to lower the reputation of the market rating. Production workers "went to the people" - to study the demand in view of social stratification. Case is troublesome, reaching definitions are not as accurate as we would like, but even on a provisional level, it serves as a basis for production planning orientation. [3]

Information work market - is universal. It is included in the essence of the functioning of the market and changed throughout the history of the market. Is no less obvious that the market information is often developed faster the base of the market, has formed a separate segment of the market reality that has as its main reason for the increased competition between manufacturers - becomes a commodity in the market more and more, and growing number of manufacturers. The market itself will eventually become the subject of competition, actively involving advertising and dissemination tools.

A quality product that meets the immediate needs of the consumer, needs no advertising. Advertising market was the name of the manufacturer, in Russia and in Europe recognized manufacturers added to the logo of their trade mark "supplier of the court," the ruler of the state. Trade was part of the production and carried out under the control of the owner. Take, for example, Ivanovo manufactory, bakeries Filippova Moscow, jewelery Faberge. Advertising has been a consumer rating, by the way, the ideal of advertising as an objective information activities and should be an assessment of the product of public opinion. Today, the ideal criteria for advertising practices do not write and do not speak. Advertising not only separated from the data stream constructed on the objective data, made purely commercial event, defining it narrowly pragmatic quality in the interest of the seller. Seller has replaced the manufacturer by the wayside. As for the buyer, in the stormy sea of advertising it is akin to Ivan Aivazovsky depicted the people in the painting "The Ninth Wave", tied to the mast debris and trust in the help of God. The best advertising slogan - "Do not be fooled - you do not sell!" Based on the "qualitative analysis" of advertising, we introduced the concept of "quality of advertising" by opposing his real quality. "Real quality", in turn, is not a simple problem. 


\begin{tabular}{|c|c|c|c|c|c|c|}
\hline \multirow{4}{*}{ Impact Factor: } & ISRA (India) & $=3.117$ & SIS (USA) & $=0.912$ & ICV (Poland) & $=6.630$ \\
\hline & ISI (Dubai, UAI & $=0.829$ & РИНЦ (Russia & $=0.156$ & PIF (India) & $=1.940$ \\
\hline & GIF (Australia) & $=0.564$ & ESJI (KZ) & $=8.716$ & IBI (India) & $=4.260$ \\
\hline & JIF & $=1.500$ & SJIF (Morocco & $=5.667$ & OAJI (USA) & $=0.350$ \\
\hline
\end{tabular}

International instruments in order to achieve consensus notion of "quality" deliberately simplify defining either as a set of specific properties of the goods, services; or as a high level of ability to meet the needs of the user. Hence the desire to formalize the quality, to bring it to quantitative characteristics to the end of the process to receive the technical problem. Plurality of representation of quality is a prerequisite for the quality of the manipulation, the highest of which is the demonstration of the "work" with the quality of advertising craftsmen. Production only makes sense as a way to meet the needs of the user, thus the quality of the product reaches a peak characteristic in recognizing the user's name, even though the quality of objectivity is revealed by the manufacturer as a specialist. In the old days the shop and manufacturing production problem of mutual understanding and bilateral meet rested exclusively in the high cost of production. The clock in the time of Huygens - the creator of the pendulum mechanism were available only to very rich buyers. Huygens made the clock gave the king of France. Louis asked, how long they will serve? Huygens answered them with a constant degree of accuracy will satisfy your descendants. Metal tableware calculated for generations. This product did not have to demonstrate the range was also limited. Relationship producer and consumer, as a rule (when it came to consumer durables), provide direct information was objectively given, guaranteed by the manufacturer and the product taken for granted.

Advertising felt freedom and on the quality and objectivity of the responsibility for the implementation of the advertised product, when market information is lost direct contact with their subject base ceased to be essential, go to phenomenal level - won the art of "file" item. It is interesting to trace the nature of the evolution of the fine arts and the art of advertising. Realism in painting at the junction of the XIX and XX centuries gave way to Impressionism popularity. If the realist sought to recreate the objective reality in the context of human aesthetic feelings - the landscape was intended to show the beauty and power of nature, portrait - to reveal the spirit of the individual, based on the originality of the depicted object, the subject of the Impressionists made their play of light, creating new technologies in art. The reality of the depicted object are saved, it is easy to see, but the viewer sees an object through interaction with light, the effect of which is transferred to the innovative technology show. From Impressionism, a new concept in the painting - "plein air".

The transformation of the information is similar to the evolution of painting and advertising commensurate with the approach to the subject that gave rise to an open-air art. Product advertising can not be excluded. Elements characteristic of the advertised product, must be present in the advertising of such items from the Impressionists, but to depict the product? It already belongs to the creator of the advertising of the product, the market of mass production "consumer" society, practically does not limit the freedom of fancy advertising. The difference in the form of risk. Impressionist risked himself could remain without a buyer, and go bankrupt, advertiser, in the worst case, lose time on some of the confidence in their competence. Information the beginning of the organization of market relations clearly showed Z. Nozhnikova - cultural historian, collected in his monograph "The Curious Moscovia" notes Western ambassadors, visited in Russia in XVXVII centuries [6]. The vast majority of Europeans who visited Muscovy official visits as part of embassies, were surprised by the consumer culture, construction, order and ... prices in the market. Many made his fortune, he returned home, on the differences in prices of goods bought and sold in Russia at home. Then the information about the quality of Russian products and their actual price was strictly objective, as it should be the information received for it, as they say, from "first hand" - from merchants or producers. And those and others have acted within the rules established by the authorities under the supervision of the king's orders. Based on documentary sources ( $\mathrm{P}$. Petreius, P. Allepskogo, I.-F. Kilburgera et al.), Z. Nozhnikova concludes: "The most interesting thing many foreigners seemed markets. In the markets was something to see (ie, product advertised himself better than any customized ads. In walking through the market could successfully combine important business of studying trading state in Muscovy ... ask the price for future purchases, which, as gifts to relatives and friends, you should buy before the return trip, and - perhaps most importantly - to marvel at the wonders of wonders, as he called Moscow Airman market .. Markets in Moscow and Arkhangelsk worked as an advertisement of itself Muscovy, were its hallmark for the Europeans, who did not know Russian. It is highly unlikely that the current Europeans from Russian markets have experienced the same feelings with which their ancestors had left the market. In Central Asia, there is a saying: "No matter how many say halva, halva, halva, sweet in the mouth will not be." It perfectly describes our politicians, liberals, alleging market achievements of the Russian Federation. It remains to add to the above that the market, as economic phenomenon, reflecting both a political reality. The market can be released to float freely, or to introduce him political control in the interests of the social spectrum, it is our national toy "roly-poly", will remain an indicator of the quality of political management of the economy. And ads here performs the same function as the concertmaster of the symphony orchestra - adjusts the sound. Normal market, that is really free and fair organized by the trade, regardless of the size and position of the seller, with the need to provide the information required. All 


\begin{tabular}{|c|c|c|c|c|c|c|}
\hline \multirow{4}{*}{ Impact Factor: } & ISRA (India) & $=3.117$ & SIS (USA) & $=0.912$ & ICV (Poland) & $=6.630$ \\
\hline & ISI (Dubai, UAI & $=0.829$ & РИНЦ (Russia & $=0.156$ & PIF (India) & $=1.940$ \\
\hline & GIF (Australia) & $=0.564$ & ESJI (KZ) & $=8.716$ & IBI (India) & $=4.260$ \\
\hline & JIF & $=1.500$ & SJIF (Morocce & $=5.667$ & OAJI (USA) & $=0.350$ \\
\hline
\end{tabular}

other information is superimposed on objective and intended to elevate objectively, cultivate the original objective information product. "Attractiveness" of the advertising category is transformed into an economic, or rather - a market brand. Theoretically and methodologically even "appeal" refers to "through" concepts that characterize the activity and its products. It is unlikely that there are opponents of this statement. The essence of the consideration of "attractiveness" in the light of our problems is not in the definition of "appeal" as such, but in its concrete historical manifestations. Activity - a way to implement the idea, is the idea of practice will not go beyond the element of consciousness is knowledge and is likely to lose after a time value. Relevance, meanwhile, lies not in the activity and in the process of realization of the idea, a method of the same activity is regulated by the space-time coordinates, and revealing relevance limiting mode of action. History is made up of actual historical periods - the actual stories. Historical phenomenon, regardless of its nature - material or ideal, it is not when accomplished, but only if included in the historical chain of events. In the dialectic of social development so described by a pair of categories, "historical logic", and historical phenomena can "fall out" from the logic of the historical process that is natural. Otherwise, the development involuntarily forced to think about the divine creation of social history. when it included in the historical sequence of events. In the dialectic of social development so described by a pair of categories, "historical logic", and historical phenomena can "fall out" from the logic of the historical process that is natural. Otherwise, the development involuntarily forced to think about the divine creation of social history. when it included in the historical sequence of events. In the dialectic of social development so described by a pair of categories, "historical logic", and historical phenomena can "fall out" from the logic of the historical process that is natural. Otherwise, the development involuntarily forced to think about the divine creation of social history.

"Attractive" in the broader context always stimulated activity. In recent history, this concept has acquired a new meaning and a new value, respectively. It turned out to be at the center of economic contradictions in the market. It actively exploit the advantage of all those for whom the market - the main source of speculation, they will go on "Breaking Bad." It sees salvation consumers are those who preserve the honor of the professional manufacturer. The question arises: why is it so stable position on the market speculators? The issue is divided into two parts. The first part - at whose expense they have their "margin"? The answer is simple - they are fed producers and consumers, of course, not willingly, of necessity, obeying the order of regularities. The second part - why it is so prescribed by law and that takes power on all its levels, to be the power of the people - democracy. At this point we have to stop asking. Prompt response statistics. In quantitative terms, compared with the Soviet period, the government significantly strengthened by branching, increased from two to three times the number of its employees, the financial capacity to ensure their well-being and fusion with legal marketing business. It would seem likely to "appeal" to draw in the interest of production and consumption is small. So it is, but objectively they exist. [3] It would seem likely to "appeal" to draw in the interest of production and consumption is small. So it is, but objectively they exist. [3] It would seem likely to "appeal" to draw in the interest of production and consumption is small. So it is, but objectively they exist. [3]

Let us try to approach the problem systematically and comprehensively. Dissemination of scientific knowledge in the modern systematic and comprehensive approaches are successfully combined with each other, making it possible to look at the subject of study in two basic projections: from the outside (on the side) and from the inside. An integrated approach to production planning is necessary to analyze all the facets of the subject operation to achieve not just limit the objectivity of knowledge, but also get the "bulk" of knowledge about the subject matter, exclude the possibility of omission of any significant manifestations of it. We often hide behind the accident. It usually happens when we forget the origin of the accident. Randomness is born at the intersection of necessities. Prevention of unwanted random events is based on the active involvement in the learning process and management of an integrated approach. Systematic approach reveals the inner secrets and gives the "keys" to the management of the subject itself. In XX century the concept of "system" fell in a number of key methodological concepts of philosophy of science. "System, a plurality of elements in the relations and relationships with each other, which forms a certain integrity and unity." The systemic nature of the construction of knowledge (or phenomenon of reality) is defined as follows: the object of analysis is conventionally divided into components, if the sum of the properties of all parts of the system does not match with the sum of the properties of the system itself, it is the system in front of us. The relationship of parts of the system cause synergistic effects, which is the reason for the discrepancy amounts of property values. The system is also characterized by a special factor forming system, it is defined as a system. System-forming factors may be monistic - so, for example, grows a crystal on the same factor D. Mendeleev built Periodic system of chemical elements, the first to understand the significance of differences in the atomic weights, or duality. For a long time we could not decipher the systemic basis of 


\begin{tabular}{|c|c|c|c|c|c|c|}
\hline \multirow{4}{*}{ Impact Factor: } & ISRA (India) & $=3.117$ & SIS (USA) & $=0.912$ & ICV (Poland) & $=6.630$ \\
\hline & ISI (Dubai, UAI & $=0.829$ & РИНЦ (Russia & $=0.156$ & PIF (India) & $=1.940$ \\
\hline & GIF (Australia) & $=0.564$ & ESJI (KZ) & $=8.716$ & IBI (India) & $=4.260$ \\
\hline & JIF & $=1.500$ & SJIF (Morocce & $=5.667$ & OAJI (USA) & $=0.350$ \\
\hline
\end{tabular}

genetic function of DNA until the thought came to bifurcate its chain. It seems that the DNA strand is born relationships between two bases, functionally interdependent - and element properties. They seem to be "attached" to one another, thanks to which there is a double helix of DNA. Marx, as we have already noted, the construction of the system revealed the product, presenting the product as alienated product having exchangeable and consumer costs. System status of the goods determined the order of relations in the commodity market, but not immediately. Adam Smith understood why the increase in labor productivity is not accompanied by an increase in workers' wages. Political economy, as a science that penetrates into the logic of the system of relations that determine the existence of the wound, but not its reality. reality of the market - it is a different system, different from the existence of the system of commodity production. Market due to the sociopolitical reality, so the market and there is that does not enter into the logic of commodity production, however, is actively functioning infrastructure. Formal logic is simple: historically requires the mutual satisfaction of interests of producers and consumers. Only then the story will be the same "reasonable story" "reasonable person." The real story of it appears to be irrational.

A factor which the construction of the concept of product attractiveness, in our opinion, should be the ability of the product to cause the need for an urgency. Buyer's little interest, the interest is necessary to give form to an actual need for the proposed product. Need - a key indicator of psycho-physiological mood of the person. "The needs - the need of a living organism in something that is necessary for its life and development needs ... create motives." In the scientific literature there are several attempts to classify human needs. Unfortunately, none of those that are known to us, not the system. Most often it refers to the "pyramid of needs" Maslow.

Maslow believed that based on the analysis of the degree of satisfaction with the above requirements, you can build an effective management of the company. Some authors, such as BS Aleshin, LN Alexander, VI Kruglov, AM Shalom confirmed that "for the time of its use has been made a number of refinements," and in general, it "has become an essential tool for the activities of the manager." In our understanding, "Maslow Pyramid" is interesting as a general approach to the configuration needs. It lacks cultural - moral and aesthetic needs, knowledge and skills needs, in physical development and health. Physiological needs are traditionally incorporated into the base design, which obviously limits their functionality. human needs, the system should be built on the principle of duality of human nature. Dualism of human nature somehow manifests itself not only in terms of base and superstructure, but also operates at all levels of private and public life of the individual.
Besides it is necessary to emphasize the sociotemporal and socio-spatial specific needs, the value of their relevance.

The concept of "attractiveness of goods" partially revealed in the term "value of the goods." It is defined as "a set of expected parameters the required quality consumer goods to him and their values satisfying consumer demands" In the literature "value goods". value of the goods scanning is called "the tree of customer satisfaction." To the value of the goods has caused customer satisfaction, it is important to not only be concerned about the quality of the goods, but also remember that the mind of the consumer is not constant, it moves, is maturing. The term "client is ripe" describes the process of interaction between producer and consumer. The consumer in this reaction is represented by mental activity first. Sources mental readiness to accept the offer as a producer coinciding with its own concept of the attractiveness of the product uniform. Normally, it is referred to:

- authority of the manufacturer;

- information from sources believed to be reliable;

- consumer communications, networking;

- product presence in the past experience of the buyer;

- the relevance of the purchase to the buyer.

If the goods are psychologically attractive image as formed, the phase relationship of the abstract possibility of moving to a real possibility. The next step - a real transformation of opportunities into reality the acquisition of liked the product will depend on the ratio of producer and consumer costs. For the first, it is a question of the relationship between costs and prices, for the second - the price and quality of the product. J. Juran emphasized the special place in the structure of consumer demands quality services.

Summing up the analysis of the concept of "product appeal", its relationship with its immediate economic concepts, methodological expedient to arrange the relationship of these concepts systematically. In order to judge us - who is right and who is not - the authors have decided to take advantage of clarifying the status of the appeal of the product concepts with the help of leading experts, teachers, and students who are on their activities closest to the customers in their communication merchandisers.

In the current market conditions, the competitive environment and the direct interaction of Russian and foreign manufacturers addressing a combination of state and market competitiveness of governance is becoming a strategic resource economy SFD and North Caucasus Federal District regions. The world economy took place price competitiveness competitiveness levels of quality, which will enhance its relevance to Russia's entry into the WTO. The increase in the quality factor performance of the domestic production of shoes in the strategy of competition on the world markets is a long-term trend. 


\begin{tabular}{|c|c|c|c|c|c|c|}
\hline \multirow{4}{*}{ Impact Factor: } & ISRA (India) & $=3.117$ & SIS (USA) & $=0.912$ & ICV (Poland) & $=6.630$ \\
\hline & ISI (Dubai, UAI & $=0.829$ & РИНЦ (Russia & $=0.156$ & PIF (India) & $=1.940$ \\
\hline & GIF (Australia) & $=0.564$ & ESJI (KZ) & $=8.716$ & IBI (India) & $=4.260$ \\
\hline & JIF & $=1.500$ & SJIF (Morocco & $=5.667$ & OAJI (USA) & $=0.350$ \\
\hline
\end{tabular}

In Russia, as in most Russian regional entities, there are all necessary conditions for the development of production in the national interest. If somewhere something is not enough, it does not serve as the basis for the recession and downturn.

In the mid-2010s the country was in an economic situation like the end of 1920 - beginning of 1930 . Then there was a question: to be or not to be a new social order, I wish the people (for "chosen" is always adapt to any situation). The response was not hidden in the maze, and LM Kaganovich did not need the Ariadne's thread to get in search of the key solutions to the problem of the secret source. He needed the blessing of the leader. And I.B. Stalin agreed that "cadres decide everything". From myself to clarify "professionally trained and politically responsible for the result." Explanation important because democratic reforms in Russia miraculously removed the first thing the professional responsibility for obvious defects in the policy.

All policy and has always been understood as an activity in the public interest. Political responsibility in a democratic society-furnished - the highest form of expression of professionalism. Failure of political promises and declarations - indicates either a failure to engage in politics, or the use of political governance in the private interest. 85 years ago for obvious consciousness and it was as such in practice. In vain, speaking of cruelty IV Stalin, forget that every flaw in the policy is reflected in the position of the people, not the politicians, managers, consultants, advisers.

In the interests of restructuring of the economy on a path to increase in commodity production, the share of added capital - essentially modern industrialization, we must begin not with the economic and with the scientific and technical activities - a political renaissance. Of course, the new time requires different tools than the action of the second half of the 1930s, but the essence has to be invariant. Political efficiency - higher professional criteria. Interpret this finding to the contrary better. Not reached until actual reality claimed change retirement community managers followed characteristic depending on specific conditions and the size discrepancies.

In Soviet times, it was distributed to the party Slang - "put in a position of responsibility"! No one knew exactly what and how to do it, but everyone knew, if not complete, it will be bad. We have the same reason, the responsibility shifted to the market. Responsibility for the implementation of specific policy areas, losing a personalized view, ceases to be a liability. Duma we would never respond. The Government is responsible to the President and the Duma. Personal responsibility before the people only the President. Hence, the only decent rating national survey. Undoubtedly, it helped President patriotic policy - consistent, active. But, it seems that the main factor, although not clear, the President's popularity in contrast to all in positions of authority, is its practical capacity,

Unfortunately knots tied economic incapacity and impunity, will untie the President, and responsible for solving the problems facing society, will continue to openly pull time under the guise of uncertainty of interpretation of modernization, our general task "to get off the dependence on raw materials" - 55\% of tax revenues It will not be solved.

Personification of responsibility does not mean the search for the person who is responsible for everything. Personification involves delegation of responsibility for obtaining the desired result. Here it is essential to realize that the "team" - not the company of like-minded colleagues, partners; "Team" - the chain of responsibility, due to the specifics of objects and solve the problems of its modernization. for the outcome of the responsibility should not be preprinted in the bowels of the team. Responsibility even for the team result always has a personal expression that focus not want to recognize our high managers. That's according to the desire - "to push" all the specifics of the control object, the unpredictability of demand, currency volatility, it is unclear tariff changes and the like, can be attributed to the pressure "from above", by which prove to us that the management - the professional direction,

A curious fact, however, is not the history of the "light" industry. DI. Mendeleev in the early XX century, was given the task of the Government to deal with the modernization of the secret of gunpowder in Germany. Not having direct access to German technology, chemist requested monitoring the movement of freight trains in the areas where the powder is produced from tracking the beginning and end of the route. He deciphered the German recipe and developed recommendations for the Russian Government on the basis of the information received. Would have been in his place economist clean, modern top manager, the result would be completely different. He would have stuck in the statistical and financial calculations of costs, revenues, and far away from the political, scientific and technological components. The most serious methodological error economic policies to reduce economic analysis.

Economic science emerged and developed in the context of politics, as political economy. Today, economists in the policy are not guided by political economy and economic policy. Instead of investing in the development of production are hiding money in foreign banks, reduced funding for education and selfeducation, increasing the number of the poor, do not index pensions, denied aid to farmers, etc. "Manilovs' nineties changed" Plyushkin "tenths.

Basic and invariant superiority of Russia lies in the geographical position, combined with the absence of the danger of overpopulation of our space due to natural increase. We have a natural and solid margin of safety for centuries. Rather than pressure the past 


\begin{tabular}{|c|c|c|c|c|c|c|}
\hline \multirow{4}{*}{ Impact Factor: } & ISRA (India) & $=3.117$ & SIS (USA) & $=0.912$ & ICV (Poland) & $=6.630$ \\
\hline & ISI (Dubai, UAI & $=0.829$ & РИНЦ (Russia & $=0.156$ & PIF (India) & $=1.940$ \\
\hline & GIF (Australia) & $=0.564$ & ESJI (KZ) & $=8.716$ & IBI (India) & $=4.260$ \\
\hline & JIF & $=1.500$ & SJIF (Morocco & $=5.667$ & OAJI (USA) & $=0.350$ \\
\hline
\end{tabular}

for irrationality in politics and economics, should pay for the actual merits of our ancestors, who managed to gather Russian and nations around Russia. Concerned not so much the decline in production, squandering of what has historically manifested its national identity, national traditions, as the possibility of loss of employment talent Russian peoples alarming inefficiency of the system of economic policy.

Progress does not happen without a derogation, the slowdown in the movement of recessions. Policy aims to active, targeted actions to help to overcome the obstacles encountered in the development. Politicians must stay ahead of the economic movement and guide it, to stimulate domestic economic factors political leverage, to clear the way to economic efficiency. Instead, the politicians continue to bind development plans to the price of oil, the ruble amount of European and American currency, referring to the integration trends in the world and globalization.

Integration of transnational relations - an objective reality, but for all its objectivity, it does not deny the specifics of national economic progress. Moreover, the integration objective is designed to contribute to national development. Why do we then do not get how it should be? This question arises from the logical comparisons policy in strengthening the defense, restore the international prestige of the country in the most difficult circumstances, the formation of a new world architectonic to the fact that year after year the Russians observe and fully feel the in the rest of the economy - we do not accidentally the two governments? The second "shakes gas and inhibits" simultaneously.

Prolonged recession in the Russian economy has: two ways of explanation. The first - the people have lost the ability to work well, squandered "human capital", the second - control helpless. The media claim that politicians know their stuff, keep things under control, take the necessary measures and promise to change for the better in the near future. Hence, the reason is the poor performance of the performers and the unfavorable world market conditions.

How much you have to be naive to planning economic policies, based on sincerity, selflessness, compassion competitors? The Russian president has long said that our Western partners do not want to strengthen Russia, they need obedient Russia, such as the Baltic republics of the former USSR. I did not want to sadden the politicians responsible for the economy, but, according to Aristotle, forced to admit: "Friends of the East too canny" - meaning "Plato is my friend, but truth is more expensive." They will help us at least benefit from such assistance itself.

It is time to realize that all the economic and political alliances in the modern world space - is an attempt to achieve national win in an environment of transnational relations, ie, partners can count on until it is advantageous cooperation. Which implies the conclusion - you need to stand face to its economy. Only in this way, even with a lot of stress, it is able to solve their problems. There is, for example, these objective reasons that would justify the decline in production for over a quarter century in the light industry.

Light industry is closely related to agriculture, really dependent on the work of the latter. Only to such interactions must be approached historically specific, relying on scientific and dialectical analysis. There are old meteo calculations showing that of the 10 calendar years in Russia 5 unfavorable for the development of agricultural production $(2+3$ and $3+$ 2). In determining the "Five-Year Plan" as a planning measures were based on this law. [4]

The problems of agriculture and light industry is not in their specificity, they have always been political. In the United States, Europe, farmers have a lot of our problems. The difference is that there is a farmer - a national problem among the most important, fundamental. Its important for consideration of the existence of politicians. On how the policy is to promote a settlement, estimated public places policies. Farmer and politician linked economic policy. They balance on one taut economic stress "rope" viability.

Nothing similar in Russia. Recall the story of the last of Agriculture Ministers. In the Soviet Union there was the Ministry of Light Industry, which emphasized the importance of the industry. What prevents the importance in terms of import declarations and to develop its own production to restore equality in industrial control. "Calico edge" without light industry still that his own nature without birch groves or lyric poetry without creativity Esenin. [four]

Reformers 1990 fate Homeland domestic and industrial care less identity. They lined up on the ease of business to maximize profits and walrus placed away from their ancestral lands. Light industry has traditionally been a difficult problem to manage. Managers need to be, above all, patriots, or light industry did not raise. understanding of "long money" national importance it is also necessary. Compensating the difficulties to become demand stability.

What is the policy ineffectiveness in the economy end of last and the beginning of the new century? This question №1, and we are talking not so much about who is to blame. We are interested in the essence of the political paradigm, developed by those who turned out to be "at the helm". Question №2 - that should be changed and how, apparently, it is necessary to do to raise the national industry, clothing, footwear, leather goods, textiles, accessories, not least?

The answer to the question №1 simple - no one was going to develop a paradigm of economic policy aimed at a radical transformation of the basis. reforming method (not without help from) decided to 


\begin{tabular}{|c|c|c|c|c|c|c|}
\hline \multirow{4}{*}{ Impact Factor: } & ISRA (India) & $=3.117$ & SIS (USA) & $=0.912$ & ICV (Poland) & $=6.630$ \\
\hline & ISI (Dubai, UAI & $=0.829$ & РИНЦ (Russia & $=0.156$ & PIF (India) & $=1.940$ \\
\hline & GIF (Australia) & $=0.564$ & ESJI (KZ) & $=8.716$ & IBI (India) & $=4.260$ \\
\hline & JIF & $=1.500$ & SJIF (Morocco & $=5.667$ & OAJI (USA) & $=0.350$ \\
\hline
\end{tabular}

choose from ready-made designs. For a model is proposed to take the Swedish experience, the Polish "shock therapy" reforms in Portugal, Argentina. So innovators, scientists brave and wise organizer as Gaidar, Chubais, Koch, Burbulis not come up with the idea, which usually begins to charge the owner - than I have, something to copy ..

Politics is not done according to the state of feeling. Like it or not - the level of consumer perception of the world. With this approach to the "political kitchen" be harmful. Economic policy does not fit the "good" or "bad", "effective" or "ineffective". She has a right to be called a "useful" or "harmful". Too high price of such policies, respectively, and the responsibility is not limited to professional form. Politics is politics. Apolitical and unprofessional to make politics a source of income of their own.

Whatever the economic situation did not develop extremely dangerous absolute value of economic criteria, give them the property of universality. Engels sharply opposed the attempts to bring the teachings of Karl Marx on the social development of "economic materialism", "economic determinism." Economic basis - the basis of social organization, but not systemforming factor of its improvement.

Society - system of human relationships that take place in the dynamics of economic activity. Activities - social life means people. Activities necessitating different kinds of relationships - the way of manifestation and human development. Relationships are designed to ensure that human development. About the fact that the form of property to be changed at the end of the XX century did not speak only dumb, but that relationship, born ownership, pulled by a distribution of the manufactured product, or its cash equivalent, that the exchange can not fully trust the market, control functions need to be kept by the state converted democratically, that perversely bureaucratic form of government is a generator of corruption, tried to keep silent, knowing the sensitivity of property reform.

Most people have no relevance as to who the owner is, not everyone wants to try on the role of the owner - to turn, to spin, to fight, to risk. Distribution on the contrary, applies to all, and the poor and the nonpoor.

Reliability and versatility - attributes of quality of knowledge. Reliability to minimize risks, flexibility relieves tension with the search for new solutions to the problem - "from the good deed goes unpunished." For quality comes at a price. Board, as is commonly believed, has a financial relationship, but it does not always look right. In the history of civilization, there are two outstanding achievements at the level of revolutions, is clearly not an equivalent assessment, namely:

price discovery knowledge, comparable to the cost of human things, "knowledge - force"; awareness of the special significance of theoretical knowledge in the form of concepts and related forms of abstract thought - judgment, reasoning. This naturally led to the need to develop a specific technology of production - methodology knowledge of the essence of relations existing phenomena. The visible part of the world "designed" to the consumer, unseen - on the manufacturer. manufacturers competition can be formalized as a simple technical problem - to get through a lot of chaotic phenomena of the visible part of the world in its hidden part, to understand it, to come back and understand chaos as the order of coexistence and development of the phenomena. Order and there is regularity. Laws exist only in textbooks on their own, separately.

Economic science in the XX century came in a difficult situation, which is the end of the century, had become critical. The theory of Adam Smith and Karl Marx method does not fit into the contours of the developed capitalist ideology. In Europe and North America, the very idea of capitalism historicity perceived as heresy. The history of capitalism has a beginning, but the presence of the start can not be the basis of the output of the limbs. Math - an exact science, it allows infinity to one side. The dialectical interpretation of infinity - the metaphysical, abstracted from real history. Rescue of economic science can not be found in the historical and formal-logical sense of reality, that is in mathematical calculus, statistics.

We will stop dipping into the philosophical, rather, in the methodological foundations of science, but not because it is necessary to plunge quickly into practical business, and due to the importance for the successful realization of the production of goods understanding that all production implies reproduction, along with commodity relations. Production begins with the achievement of certain relationships and leads to the development of these relations - between producers and consumers. To understand such a complex production can only be built with the involvement of the scientific analysis on the basis of conceptual thinking.]

That is why the start of the comparative analysis of the new concept of "attractiveness" in the application of its specific terms "product appeal", we have a theory of logical exercises. An alternative way is, but without the light source, groping in the dark.

Current knowledge about the concept; his ascent from the abstract to the concrete, followed by the prospect of the creation of new product concepts as content development, laid Hegel. Conceptual thinking, according to Hegel - dialectical process. The doctrine of the world-famous philosopher, was based on a fundamentally new interpretation of the development, which was based on the idea of an internal source movement, represented by the opposite attitude, being in unity. Preceded by Hegel, Aristotle, logic thinking built on the concept of the principle of identity itself, its immutability. The 


\begin{tabular}{|c|c|c|c|c|c|c|}
\hline \multirow{4}{*}{ Impact Factor: } & ISRA (India) & $=3.117$ & SIS (USA) & $=0.912$ & ICV (Poland) & $=6.630$ \\
\hline & ISI (Dubai, UAI & $=0.829$ & РИНЦ (Russia & $=0.156$ & PIF (India) & $=1.940$ \\
\hline & GIF (Australia) & $=0.564$ & ESJI (KZ) & $=8.716$ & IBI (India) & $=4.260$ \\
\hline & JIF & $=1.500$ & SJIF (Morocco & $=5.667$ & OAJI (USA) & $=0.350$ \\
\hline
\end{tabular}

mechanical theory of this approach is reflected in the "static" section, and the specialist knows that in this way the situation is artificially simplified private interests. But then come the most interesting topics in practical terms "dynamic" and "kinematics". They describe is not the time movement - generally interpreted as something that is not me, resting in his state, and the movement as a change in the broadest sense. Until the dynamics and kinematics of the more thinking in the context of the content of the concept of motion Aristotle got it primarily interested in abstraction and generalization of the technology in the form of knowledge. Aristotle's logic so often referred to as "formal".

From the point of view of Hegel, Aristotle's logic was merely a special case, having the value of that knowledge in order to integrate into the process and to make a general reconnaissance of important, albeit conditionally, to stop the change. Aristotle sacrificed content of concepts in order to achieve regularity of formal relations. Simply put, the view of Aristotle's logic is akin to the expression "the general plan" for the time being. Past and future concepts of Aristotle was not interested in that, once again, in general, consistent with the nature of historical time. Karl Jaspers called the era described by the "axial age", stressing the role of culture as an axis around which to spin the beginning of the ancient civilization, but it is hardly necessary to see in his estimation the actual historical scale of the changes taking place, and the concept of time itself Greeks were cyclical. In short, Aristotle in his logic reproduced the spirit of the age in which he lived and worked. Another thing Hegel, worked in the conditions of modern times heyday with its political, scientific, technical, industrial and cultural revolutions. Hegel was necessary to understand the spirit of the time in the context of radical social change, to fill the contents of the concept of motion.

After Hegel himself has left a lot of questions, therefore, paying tribute to his dialectical discovery, one should remember that the Hegelian legacy that hindered the spread of the dialectic.

By limiting the scope of the dialectic of spiritual activity, he admitted being self-sufficient spirit and took the rest in the form of other-being of spirit, of course, is the dialectical development. The triad of Hegel "thesis - antithesis - synthesis" was not the universal development of the formula. Non-spiritual the existence of forms of life - physical human reality, nature, society, he explained the objectification of spirit, referring to derivatives of the spirit. The merit of Marx and Engels consisted precisely in the fact that, based on the natural-scientific discoveries and the movement of the bourgeois mode of production, they first turned the understanding of dialectics "upside down", and then removed the restrictions on her and made universal way development [5].
A reaction to the rationalism of Hegel were positivism and irrationalism, but they suffered the same "disease" as "sick" - one-sided approach. Positivism is clearly experiencing the limitations of empiricism, irrationalism was closer to the time of the bourgeois activity, not burdened with intellectual reflection, the idea of willpower, desire for power, received some support in developing society, in spite of the number of areas of reasoning in terms of cultural traditions.

Proof of this is the next surge of interest in Europe by Karl Marx Economic Research at the end of the zero years in connection with the financial crisis. Europeans do not know that there is another major monograph VI Lenin's "Imperialism, the Highest Stage of Capitalism," in which the author first analyzed the outperformance of financial capital and said it outright desire for political influence on public life.

Dialectical thinking did not come into the economy immediately, it began with individual ideas, mainly the development of ideas. Italian economist A. Serra first drew attention to the division of labor (PT) and looked at this feature of economic activity in the dynamics. Statistically it is proven that the country's wealth grows, depending on the depth and spread of the Republic of Tatarstan. W. Petty and Adam Smith launched a withdrawal angle A. Serra on a transnational scale. As a result, Adam Smith was in an impasse undialectical thought - when RT coverage of the economy around the world, the development will stop? Adam Smith and David Ricardo capitalism perceived identically in world history, were convinced that capitalism appeared to be endless. Economic thought buried in a limit, because could not find the beginning of a political economic equivalent. Marx predicted,

It is no accident in the XX century, the political aspect of economic science vigorously squeezed, naively believing it will be possible to limit the purely economic analysis. Very "refined" economic science divided into macro and micro-economics, and to XXI century generally presented as a ekonomiksizm. "The new economic" science "writes ML Khazin, was created precisely as an ideological alternative to the political economy ... For this it was necessary to turn the construction of a science on its head: if political economy is based on macroeconomics (ie general economic laws, which include the deepening of the $\mathrm{RT}$, and the scale of markets and the volume of aggregate demand) to microeconomics (ie, the behavior of the individual and businesses), the ekonomiksizme the opposite, ie, ekonomiksizma specificity is an attempt to withdraw from microeconomics global macroeconomic patterns. "

Now imagine the scene - specialists manipulate the historical science, instead of improving its methodology to produce new theoretical studies, to finish building and rebuild through a systemic 


\begin{tabular}{|c|c|c|c|c|c|c|}
\hline \multirow{4}{*}{ Impact Factor: } & ISRA (India) & $=3.117$ & SIS (USA) & $=0.912$ & ICV (Poland) & $=6.630$ \\
\hline & ISI (Dubai, UAI & $=0.829$ & РИНЦ (Russia & $=0.156$ & PIF (India) & $=1.940$ \\
\hline & GIF (Australia) & $=0.564$ & ESJI (KZ) & $=8.716$ & IBI (India) & $=4.260$ \\
\hline & JIF & $=1.500$ & SJIF (Morocco & $=5.667$ & OAJI (USA) & $=0.350$ \\
\hline
\end{tabular}

approach proven ideas. Why you ask? Who needs it? The theory of knowledge on these questions the answers are not provided. The absurdity of the negation of the logical path of the obvious, but there are precedents. Famous Scientists have repeatedly stated incoherence achieve the discoveries, but they talked about the final heuristic link logically and methodically constructed a chain of knowledge. Incoherence, or rather illogic of the final results only confirm the rational perspectives thinking logically organized in both versions - Aristotle and Hegel.

In scientific concepts huge development potential. Systemic relations of concepts contribute to the emergence and actualization of new concepts. New concepts may well grow in the backbone. On the other hand, even Hegel considered important for the correct orientation in the real world, to distinguish the real, necessary and real- not necessary. The first contains the seeds of the operation and development, so that such phenomenon he called "intelligent" or "valid", the second and also has served or inhibits movement or opposes it. [5]

It seems that the science of economics and in the West and in Russia under the influence of authority of Nobel Prize winners, agreed that with the death of Hegel and Marx died, and political economy. But the impression is false. Noticing the priority of production in the construction of the economic system on the market factor modern academic economists have changed owners. In place of F. Taylor, A. Fayolle, G. Ford, A. Sloan came to market speculators type Zorroza and political guidance from economic theory are preserved.

It should be put on the history of capitalism as an ideal model of production. Formally, the combination of advanced forms of political democracy and its legal support by the state, the freedom of business gives rise to a claim to the ideal. Only let us not forget that all of the above makes it ideal in comparison with the political and legal model of absolutism, dictatorship and other anachronisms. The history does not end with financial and oligarchic capitalism with its showcases demonstration of mass consumption society. "Casting" model of social and economic models is ongoing and will go until the current model is available for the seventh part of humanity. Six and a half billion of the same homo sapiens can still afford to buy the best tickets to the cinema and see the sweet life of their own kind.

The World Conference of the elite of the scientific world in Rio strongly recommended to change the course of a business of greed on sustainable development, warning that to aggravate in the human contrasts join a global conflict with nature. Instead noosphere future generation born now will receive gas masks and protective suits, and light industry have to change the direction of development, to ensure that endangered species of mammals personal protective equipment.
Features dominant mode of production is certainly manifested in the development of economic science, but they do not cancel its political status. Moreover, economic science before you commit to another round of progress required to objectively determine the political preconditions recovery mode of production to a new level. Try to figure out what more left no heirs Adam Smith, David Hume, R. Owen, G. Sismondi, Marx, J. Mill, Spencer, T. Malthus. Socio-political philosophy or economic knowledge. In their works passed into the social history of political and policy they left as means and ends of economic promotion programs in solving problems of social development. TBN bourgeois alternative method of manufacturing an objective yet not ripened. The desire to share the history of communism, political economy in two steps and start with a socialist was blocked on one side of the politicization of the capitalist economy in the direction of strengthening of socially significant milestones on the other - an aggressive economic policy designed to protectionist conspiracy, and ordinary political deception excessively credulous Communist leaders convince socialist economic insolvency. Truth remains particular - political resources economics are due to objective historical time the mode of production in which she was born. Economic science is one of its objectivity, but its objectivity reflects historical periods and therefore has a view of the circuit composed by separate specific historical links, naturally interconnected. Perhaps temporarily such links coexist. Similarly experience had a calculated VI NEP Lenin advocated by them in dealing with colleagues and caused the rise of the country's economy, and the official political doctrine of China: one country - two lifestyle.

The modern history of economic science, in spite of the numerous tricks opponents is former politic course, the depoliticization of economic theory seems absurd in economic practice. Just look at the movement in exchange rates, stock market news to follow in order to assess the effect of political influence on economic activity.

Along with the evolution of economic science and economic concepts are changing, some are reset and filled with new content, others pushing the application area, others moved to new positions, the fourth lose the former importance at the time, as the fifth there, demonstrating the modernization of economic reality. Moving from concept to concept, you can repeat the historical logic of the ascent of production, determine the quality historic racing.

The market has become the basis of metabolic processes, and fair his complement. The nature of the market due to the need of reproduction. It entered the market in the production process, and all his attempts to get over the production of unnatural. But the very existence of the market as a way to meet the conditions of reproduction is absolutely natural that 


\begin{tabular}{|c|c|c|c|c|c|c|}
\hline \multirow{4}{*}{ Impact Factor: } & ISRA (India) & $=3.117$ & SIS (USA) & $=0.912$ & ICV (Poland) & $=6.630$ \\
\hline & ISI (Dubai, UAI & $=0.829$ & РИНЦ (Russia & $=0.156$ & PIF (India) & $=1.940$ \\
\hline & GIF (Australia) & $=0.564$ & ESJI (KZ) & $=8.716$ & IBI (India) & $=4.260$ \\
\hline & JIF & $=1.500$ & SJIF (Morocco & $=5.667$ & OAJI (USA) & $=0.350$ \\
\hline
\end{tabular}

allows the market within certain limits be its rightful position in the industry. Exercise the same self, as we all know, can be different, especially as the market connects the interests of different subjects of production, each of which wants to be a winner.

Production combines not only technical and technological actions, their objective affiliates, it includes the "human factor", which in recent years often called "human capital" - this sounds nicer instills pride in the right to be a "homo sapiens", moreover, almost capitalist. "The human factor" more accurately describes what is happening directly in the production, since production can be decomposed without residue on the basis of the concept of "factor" on the components of "didactic" unit. "The human factor" brings to the production goal, if you're lucky with the "human capital" - a professional management culture of the target can "grow" expediency, that is systematically organized relationship goals, means, methods and forms of its achievements, to optimize the production process. In general, the production looks like a work of turning goals into results. The correct choice of the purpose of production is considered the first victory, the "good beginning" that folk wisdom is equated with "half of the case."

And yet, the "end - around the crown of the case." The goal is realized, it produced the desired result. It begins a new story. The result was not produced for own consumption. That production is not stopped, and the victory was Pyrrhic not, the resulting product is in the rank of the goods to be exchanged on the necessary conditions for the continuation of production. The case turns on the market, whose task is to attach the goods - to find a buyer. The buyer, of course, their own interests, perhaps not entirely private, in contrast, primarily manufacturing. To some extent the market - it is also the production, it makes the organization of mediation services. This production, however, is more like a erzatsproizvodstvo, for it is not the function of creating a value-added product, but an active influence on the change in price of goods. The concept of "price" - the market of origin, therefore it has an indirect relation to the fundamental concepts of production "cost" and "value" of the goods. Price provides income market and the market - stakeholder pricing process. Here begins another interesting story for the buyer. The market has a great potential to manipulate the products and prices in the absence of a clear thought-out and organized interaction in system of relations of producers and consumers. Liberal political economy focuses on the freedom of the market, without having to worry about the content of the concept of "freedom". Arbitrarily interfering in the responsibilities of the philosophy, the Liberals pretend to solve their problems, misleading professional thinking and social consciousness. Not all economists, theorists and practitioners versed in philosophical reflection. Using a similar position, Liberals grow their market, "the concept of" freedom, trying to free the market from the necessity of submission to any of its terms. In fact, economic liberalism, proclaimed by Adam Smith in a specific format, transformed into a banal market anarchism. In countries with strong democratic traditions, downloaded humanistic values and social responsibility, liberalism loses its political positions, but it does have a serious roof in the face of a thriving financial capital, fat liquoring by the market.

We do not want to deprive the subject of the status of market development of cultural production. The market is no doubt it is, but to put the market in a number of common subjects of production, therefore, ignore the evidence of different treatment for the most important indicators of the development of production - the ability to increase the cost of labor.

Freedom of the market comparable to the freedom of the judges on the football field. Judges do not play, they provide the game under the current rules. They can slow down the pace of their actions, bring down the pressure, play along, but it all happens in the mind, a public and professional control and prosecuted in accordance with established procedure.

Exchange market function objectifies his only important thing to remember about how to display objectivity. Material form of objectivity - is the technological objective of production, the physical reality of the goods - really is primary and is subject to the natural basis of social life; objectivity of production and economic relations, including the organization and division of labor - "secondary" objectivity created with the creative participation of the subjects of labor - it's natural and historical objectivity. There are, apparently, a third, a transitional level of objectivity, indirectly controlled by the objective nature of the production. The market belongs to the third level. Hence, such a different reality of the market, the possibility of the organizers rather arbitrarily manipulated within the market and in the interests of the market. Engels clarified E. Dühring: "In a society where commodity production is the dominant mode of production," the market has always been very well-known abroad ... among the "business people" Due to its specific reality "in transition" from being tightly regulated production according to the relativity of the terms of exchange of natural and historical specificity, the market actually combines adequate actions with specific properties, organizing of the last their infrastructure. They hide behind the "marketeers" "Iron argument" - market "barometer" of production conditions. In this position, all the actions that, according to the classification of Hegel, not valid are allowed as needed-conditioned. Quite logically Petzold, who saved Machism solipsism by introducing a " relationship 'potential member formula being. Petzold not personified the "potential member", but it was not difficult to understand that it must be something universal, 


\begin{tabular}{|c|c|c|c|c|c|c|}
\hline \multirow{4}{*}{ Impact Factor: } & ISRA (India) & $=3.117$ & SIS (USA) & $=0.912$ & ICV (Poland) & $=6.630$ \\
\hline & ISI (Dubai, UAE & $=0.829$ & РИНЦ (Russia & $=0.156$ & PIF (India) & $=1.940$ \\
\hline & GIF (Australia) & $=0.564$ & ESJI (KZ) & $=8.716$ & IBI (India) & $=4.260$ \\
\hline & JIF & $=1.500$ & SJIF (Morocce & $=5.667$ & OAJI (USA) & $=0.350$ \\
\hline
\end{tabular}

standing on a subjective form of consciousness. Marketeers, absolutizing the situation of the market, more precisely, the exchange through the market, achieve control over production. Interest marketeers again reminds us of the power of money.

Of its objective position the market should not earn more than the manufacturers. Otherwise, production stops, and with it, and social progress. Now the situation is critical, and the first cause of the crisis is the policy of the financiers, the second - the market speculation. Prices of real goods in the market for a long time does not correspond to the value of their real production costs of delivery and sale. The problem is to liberals in one - form a mass. All the same, on the street XXI century. Therefore, the world politics in the sphere of modernization of education aimed at its "market" division. The vast majority of graduates doomed to be clerks, a small minority, mostly of their own, plus those who are especially talented pool of senior managers. It's not the name of the university, and in the interest of you, very rarely dependent on you.

The heyday of the market and its infrastructure due to the birth of mass production. On the first level of mass production market has been the most regulated task to deploy the product in the implementation of the scale of production to reproduction was dynamic. Above all dominated by the need for the production of working capital, as the benefits of mass production is the ability to reduce costs, thereby reducing costs and increasing the competitiveness of goods. A key factor to make the time of sale of goods. "Time is money". Mass production has given rise to trade principle: the user can not find what he's looking! Universal Megastore offers almost the entire product range of the product in all its possible variety, including the price. Soon cleared that the lack of certainty associated with the high cost of raw materials, energy, maintenance of premises, a large number of unsold goods, especially the limited shelf time. Market with its function has not managed as planned. Was an important event, it has not received the deserved estimation may not want to lower the reputation of the market rating. Production workers "went to the people" - to study the demand in view of social stratification. Case is troublesome, reaching definitions are not as accurate as we would like, but even on a provisional level, it serves as a basis for production planning orientation. has not received the deserved estimation may not want to lower the reputation of the market rating. Production workers "went to the people" - to study the demand in view of social stratification. Case is troublesome, reaching definitions are not as accurate as we would like, but even on a provisional level, it serves as a basis for production planning orientation. has not received the deserved estimation may not want to lower the reputation of the market rating. Production workers "went to the people" - to study the demand in view of social stratification. Case is troublesome, reaching definitions are not as accurate as we would like, but even on a provisional level, it serves as a basis for production planning orientation.

Shoe fit and came to the time of Cinderella in the fairy tale, and it's because it was the second shoe, however, market research really significantly important for all subjects. Manufacturers are cutting costs, consumers get better guarantees to purchase the desired commodity brokers are losing the old freedom to manipulate the products and prices. But also to get involved in the assessment of transformation is not appropriate. The market for three hundred years history of the development of industrial production gained a protective and compensatory mechanism of the "arrival" and below - producers, and on top - the rulers; but the saddest thing is that the market through the power of lobbyists rooted, consolidated its interests in the formulation of laws and their interpretation. His second pillar became the media, going without hesitation to any violation of the regulatory limits on commercial advertising,

Information work market - is universal. It is included in the essence of the functioning of the market and changed throughout the history of the market. Is no less obvious that the market information is often developed faster the base of the market, has formed a separate segment of the market reality that has as its main reason for the increased competition between manufacturers - becomes a commodity in the market more and more, and growing number of manufacturers. The market itself will eventually become the subject of competition, actively involving advertising and means of dissemination

The new economic reality has developed in the 1970s under the direct influence of the technological revolution. Increased technical complexity of the product, has increased the warranty period. The changes made to abandon the simplistic model of quality costs. She was born the concept of quality cost, based on the decrease due to better management of funding costs on the quality and reduce the total cost of production of the product. We are trying to make the economy leaner. Emphasis in quality management has shifted towards solutions to common problems of development of production, its standardization. G. Taguchi generally called a measure of the quality of its cost and resulted in the following calculations: one wash a shirt costs 250 yen, usually during the service shirt washed 80 times. Expenses for laundry up 20,000 yen. If you can sew a shirt, shrinkable and pollutes two times slower, the consumer savings of up to 10,000 yen. Suppose a new shirt manufacturer will cost 1000 yen more, and sales increased by 2000 yen, then the producer will receive income 1,000 yen, 8,000 yen would benefit the consumer. The society will have a savings of 9000 yen plus reducing the environmental focus of expenditures, as will be less waste from washing. 


\begin{tabular}{|c|c|c|c|c|c|c|}
\hline \multirow{4}{*}{ Impact Factor: } & ISRA (India) & $=3.117$ & SIS (USA) & $=0.912$ & ICV (Poland) & $=6.630$ \\
\hline & ISI (Dubai, UAI & $=0.829$ & РИНЦ (Russia & $=0.156$ & PIF (India) & $=1.940$ \\
\hline & GIF (Australia) & $=0.564$ & ESJI (KZ) & $=8.716$ & IBI (India) & $=4.260$ \\
\hline & JIF & $=1.500$ & SJIF (Morocco & $=5.667$ & OAJI (USA) & $=0.350$ \\
\hline
\end{tabular}

We are not against the quality of manipulation. In certain limits, this is a forced measure that demonstrates the limitations of cognitive and other capabilities. Theory should not be conservative, but the quality of the manipulation - the tactical level of management, in contrast to the strategic value and significance of quality management. Manipulation - a management tool, and it must remain private, changing business in Quality Management System.

The second thing to keep in mind the prospect of analyzing the quality of the private self. Private initiative is due to the overall political and economic situation. Socialism could be built in one country, to ensure the competitiveness of socialism was at this historic time impossible. Capitalism is still strong. The same situation and waiting for private producers. Quality product it will release. It can work steadily in an environment that is not ripe for such practices.

Of course, in our market there is a certain niche, it enjoys the most respectable part of the middle class. Niche insignificant due skinny social class and instability in a volatile economy. Nevertheless, the sector is, and at his request the manufacturers of quality products, for example, at 1,500 rubles per kilogram of sausage, shoes for 5000 and more costumes from 15,000, also exist. But what does this have to do with the market an exclusive characteristic of our economy as a whole? Is, is thus an exception to the rule that only their support. The problem of quality goods manufacturer status - on a national scale and potential of the individual, relatively well-off strata applies to it as the fate of the passengers fleeing in a boat after a storm that made their big ship.

BS Aleshin leads costs diagram of quality developed in TQM (Fig. 1).

Represented by the scheme should be read in two versions - the European-American-Japanese and Russian. They market more than three hundred years. During this time, there was a balance of market forces, and manufacturers have adapted to it. Possible correlation of factors and not perfect, but it reflects an objective position in the market, the manufacturer, seller and buyer. About our market we have said, not all, but most importantly identified. We have the power of the market by intermediaries and speculators, often appear in the same person. It is connected with them, corrupt officials. Therefore, the proportions shown in the right-hand side of the diagram, in our market look different. Especially with regard to the costs of products sold. This part Klondike for all feeding in the market, and a headache for these workers. Simply because of its advantages no one has refused. The main reasons for the lack of a civilized market of consumer goods are:

- poor development of market infrastructure, inter-regional and inter-commodity distribution network and commercial relations with the countries of near and far abroad;
- imperfection of legislation in the field of production, export and import of Russian products. Given the complex and multifaceted nature of the problems of this group, drastic measures are needed to address them, including government support, as is done in other countries. For example, the recognition of the governments of China, Turkey and some other light industrial nations a strategic industry enabling them to quickly turn pretty outdated in modern production and encourage strong development in these countries, commodity, chemical and machinebuilding complexes.

In Russia in recent years, the state has taken some steps to normalize the situation in the light industry. The Russian Government has provided a number of preferences of the industry. For the third year in the country of import of technological equipment at zero import duty and VAT. It is a mechanism of subsidizing interest rates on loans for the purchase of raw materials. Since 2014 this arrangement extended to loans obtained for the upgrade. It provides support and promotion of manufacturing exporters by reimbursement from the federal budget of the cost of interest on loans obtained for the production of export products. Although not large, funds are allocated from the federal budget for $\mathrm{R} \& \mathrm{D}$ in favor of light industry.

The effectiveness of preferences: - each ruble invested in the industry in the form of subsidies on loans, provide additional revenues to the budgets of all levels and state non-budgetary funds from 6 to 7 rubles, and for some businesses - from 20 to 30 rubles.

Carried out preventive operations "Counterfeit" interdiction light industry goods. In particular, in 2018 the result was revealed more than 700 crimes, of which the material damage on criminal cases amounted to more than 3.4 bln. Rubles. During the investigation of criminal cases seized property worth more than 164 mln. Rub., Seized property, money, valuables and voluntarily repaid the damage in the amount of more than 92.3 million. Rubles.

Many of the Russian Federation and operates a wide range of benefits, including property tax, land and others.

However, the existing preferences and solved in varying degrees, problems of the industry at the federal and regional levels are still insufficient to eliminate the impact of negative factors on the development of the industry and turn it into a competitive and self-developing sector of the economy and domestic producers strengthen its position in internal market and to compete on the world market not only with the EU countries and the US, but also with the Chinese manufacturers, Turkey, India and other countries.

Hence, the key task - to express qualitative modernization of the industry and its supporting infrastructure with the use of the cluster approach, the wide application of the best world and domestic 


\begin{tabular}{|c|c|c|c|c|c|c|}
\hline \multirow{4}{*}{ Impact Factor: } & ISRA (India) & $=3.117$ & SIS (USA) & $=0.912$ & ICV (Poland) & $=6.630$ \\
\hline & ISI (Dubai, UAI & $=0.829$ & РИНЦ (Russia & $=0.156$ & PIF (India) & $=1.940$ \\
\hline & GIF (Australia) & $=0.564$ & ESJI (KZ) & $=8.716$ & IBI (India) & $=4.260$ \\
\hline & JIF & $=1.500$ & SJIF (Morocco & $=5.667$ & OAJI (USA) & $=0.350$ \\
\hline
\end{tabular}

achievements in the field of engineering and technology of textile, apparel, leather and footwear industry, including nanotechnology and nano products.

Social and human problems caused by the state of qualitative component of personnel potential, which in many companies is in the area of critical values, and some - already behind them.

The deteriorating situation in vocational and professional training of the workforce, low wages and labor prestige lead to an annual reduction in the number of mostly young and promising workers aged $30-40$ years. Only during the decade (1990 to 2008), the number decreased by 3 times, and over the next ten years -2.8 times which led to a drop in production volumes. In this case, the measures taken by crisis management unprofitable enterprises from the government and management have not been able to influence the course of development of the structural imbalances in the industry.

Not a solution to the problems of this group will significantly affect the industry's ability to lift its economy and to increase the production of competitive products in the volumes necessary to ensure national security.

In addition, all of these problems are compounded by the impact of the global financial crisis. In a crisis, the light industry, as no one starts to feel the action of his. Even those companies that in recent years have achieved positive results in the innovative development, paying considerable attention to the modernization of production, has forced and will be forced in the next few years to reduce production and to abandon the long-term investments. This is due to difficulties encountered related to the involvement of bank loans (the proportion of borrowed funds in the working capital in recent years has reached 40 per cent), on the one hand, the increase in the volume of official imports, counterfeit and contraband products, the fall in demand and a slowdown in the implementation of many types of goods, reduction of workers and professionals - on the other hand. At some enterprises began to emerge late payment of wages from 2 weeks to 1.5 months, the suspension of the start time and according to the experts by the end of 2017 the number of employees may be reduced by 10-15 percent. This is especially true of four federal districts - the Central Federal District, Volga Federal District, Southern Federal District and the North Caucasian Federal District, is the most significant in social terms. The capital structure of the industry, being concentrated in these districts, making them the most critical areas in terms of the effects of the deepening slump in production, which increases the importance of the social consequences resulting from the production stoppage. The share of Russian goods on the domestic market will decrease even more and could reach in 2019 at least 20 percent. At some enterprises began to emerge late payment of wages from 2 weeks to 1.5 months, the suspension of the start time and according to the experts by the end of 2017 the number of employees may be reduced by $10-15$ percent. This is especially true of four federal districts - the Central Federal District, Volga Federal District, Southern Federal District and the North Caucasian Federal District, is the most significant in social terms. The capital structure of the industry, being concentrated in these districts, making them the most critical areas in terms of the effects of the deepening slump in production, which increases the importance of the social consequences resulting from the production stoppage. The share of Russian goods on the domestic market will decrease even more and could reach in 2019 at least 20 percent. At some enterprises began to emerge late payment of wages from 2 weeks to 1.5 months, the suspension of the start time and according to the experts by the end of 2017 the number of employees may be reduced by $10-15$ percent. This is especially true of four federal districts - the Central Federal District, Volga Federal District, Southern Federal District and the North Caucasian Federal District, is the most significant in social terms. The capital structure of the industry, being concentrated in these districts, making them the most critical areas in terms of the effects of the deepening slump in production, which increases the importance of the social consequences resulting from the production stoppage. The share of Russian goods on the domestic market will decrease even more and could reach in 2019 at least 20 percent. began temporary suspension of work, and according to the experts by the end of 2017 the number of employees may be reduced by $10-15$ percent. This is especially true of four federal districts - the Central Federal District, Volga Federal District, Southern Federal District and the North Caucasian Federal District, is the most significant in social terms. The capital structure of the industry, being concentrated in these districts, making them the most critical areas in terms of the effects of the deepening slump in production, which increases the importance of the social consequences resulting from the production stoppage. The share of Russian goods on the domestic market will decrease even more and could reach in 2019 at least 20 percent. began temporary suspension of work, and according to the experts by the end of 2017 the number of employees may be reduced by $10-15$ percent. This is especially true of four federal districts - the Central Federal District, Volga Federal District, Southern Federal District and the North Caucasian Federal District, is the most significant in social terms. The capital structure of the industry, being concentrated in these districts, making them the most critical areas in terms of the effects of the deepening slump in production, which increases the importance of the social consequences resulting from the production stoppage. The share of Russian goods on 


\begin{tabular}{|c|c|c|c|c|c|c|}
\hline \multirow{4}{*}{ Impact Factor: } & ISRA (India) & $=3.117$ & SIS (USA) & $=0.912$ & ICV (Poland) & $=6.630$ \\
\hline & ISI (Dubai, UAI & $=0.829$ & РИНЦ (Russia & $=0.156$ & PIF (India) & $=1.940$ \\
\hline & GIF (Australia) & $=0.564$ & ESJI (KZ) & $=8.716$ & IBI (India) & $=4.260$ \\
\hline & JIF & $=1.500$ & SJIF (Morocce & $=5.667$ & OAJI (USA) & $=0.350$ \\
\hline
\end{tabular}

the domestic market will decrease even more and could reach in 2019 at least 20 percent. This is especially true of four federal districts - the Central Federal District, Volga Federal District, Southern Federal District and the North Caucasian Federal District, is the most significant in social terms. The capital structure of the industry, being concentrated in these districts, making them the most critical areas in terms of the effects of the deepening slump in production, which increases the importance of the social consequences resulting from the production stoppage. The share of Russian goods on the domestic market will decrease even more and could reach in 2019 at least 20 percent. This is especially true of four federal districts - the Central Federal District, Volga Federal District, Southern Federal District and the North Caucasian Federal District, is the most significant in social terms. The capital structure of the industry, being concentrated in these districts, making them the most critical areas in terms of the effects of the deepening slump in production, which increases the importance of the social consequences resulting from the production stoppage. The share of Russian goods on the domestic market will decrease even more and could reach in 2019 at least 20 percent. stemming from the production stoppage. The share of Russian goods on the domestic market will decrease even more and could reach in 2019 at least 20 percent. stemming from the production stoppage. The share of Russian goods on the domestic market will decrease even more and could reach in 2019 at least 20 percent.

Change the situation can only be developed and implemented anti-crisis measures aimed at strengthening innovation, increase production efficiency in the new technical and technological level, and to create favorable conditions to ensure stable from year to year growth in production volumes of competitive products.

It is encouraging that a meeting was held August 24, 2017 in Ryazan 'on the development of light industry "with participation of representatives of government, business leaders and scientists trade with the personal involvement of President Vladimir Putin forced them - the participants - to provide answers to the president uncomfortable questions about the reasons for the poor state of the light industry, and of the failure of the tasks that were formulated in 2013 in Vologda on a similar meeting and almost with the same participants. Hopefully, at the municipal, regional and federal branches of government will decrease the deafness syndrome and desire to boycott the performance of the proposed tasks, as required to verify the president and ask about the reasons for their failure. In any case, this confidence appeared in the majority of the participants in this meeting, because the president of the Eastern Economic Forum, which took place on 8-9 September 2017 in Vladivostok in a closed meeting in a rigid form, demanded that those responsible for the failure of similar events in the Far
East, which caused the dismissal and the dismissal of those officials who are most We did not implement their tasks. Such confidence we have due to the fact that the position of the light industry arch bad and can lead to disaster, not only economic, but also social. All experts objectively expressed their views on the questionnaire he proposed to the factors to answer the main question in the headline - "To be or not to be light industry?". Another thing is that their vision on this issue can be subjective and, of course, has a right to be. But, researcher itself should decide on the findings of the a priori ranking, guided by the opinion of other scholars and researchers on issues of identity, comparing them with those obtained and taking a decision on the eligibility of their inclusion in the study object. Such a decision requires the competence not only of responding experts, but also a deep knowledge of the problems by the researchers themselves.

Encouraged by the fact that all the experts respondents are unanimous in assessing the role of assortment policy and the need for effective and innovative technological solutions, to ensure producers manufacturing these products, which would have been demanded by consumers of the Southern Federal District and the North Caucasian Federal District regions and would ensure they receive effective technical and economic indicators of the results their activities and products - its demand not only in domestic, but most importantly, in overseas markets. To reaffirm the fact that we have every reason to trust the results of the a priori ranking, developed by the authors and software for evaluating the competence of participants in the survey - long life. Especially justified is the use of software in evaluating the competence of the expert respondents, invited by the Customs Committee for their work in custom commissions. Customs executives get an objective assessment of each respondent's expert as a result of their participation in the work of the customs committees, as in this case, the expert can not but agree with obtain an objective assessment of his competence and customs committees receive method of ranking, giving preference to the most qualified and objective experts, to ensure receipt in the domestic market of products of the highest quality, and ensure the safety of the consumer.

I would like to warn the customs committees of hasty decision-making competence of the experts, if they do not have the objective characteristics obtained by highly qualified specialists. All this implies not only correct attitude to his duties, but also to the invited experts, creating an atmosphere of trust and interest in obtaining positive results of the examination. If we sum up the results of the software efficiency to assess the competence of the respondents participating in the survey, the researcher has a tool to select those respondents whose opinion has a high degree of confidence, confirmed the value of the 


\begin{tabular}{|c|c|c|c|c|c|c|}
\hline \multirow{4}{*}{ Impact Factor: } & ISRA (India) & $=3.117$ & SIS (USA) & $=0.912$ & ICV (Poland) & $=6.630$ \\
\hline & ISI (Dubai, UAE & $=0.829$ & РИНЦ (Russia & $=0.156$ & PIF (India) & $=1.940$ \\
\hline & GIF (Australia) & $=0.564$ & ESJI (KZ) & $=8.716$ & IBI (India) & $=4.260$ \\
\hline & JIF & $=1.500$ & SJIF (Morocce & $=5.667$ & OAJI (USA) & $=0.350$ \\
\hline
\end{tabular}

coefficient of concordance (W), which tends to unity. Thus, summing up the results of the effectiveness of a priori ranking and the software developed by the authors,

"Road map" realization of light industry development strategy until 2025

The plan provided for implementation of the Strategy through measures implemented during the strategy period:

* support for the creation and development of the Russian brand of clothing and footwear;

* the fight against illegal and illicit trafficking of goods of light industry;

* export promotion in the competitive light industry segments;

* preservation of leather raw materials for its own production of leather and footwear; industry

* formation of personnel potential of the

* stimulating R \& D and technology transfer;

* information and marketing support of the development of the industry;

* monitor the effectiveness of the strategy and the adjustment plan

In addition, a number of strategic initiatives will be implemented in stages:

Step 1: The main activities implemented in the period 2015-2017 .

- preparation for the implementation of the strategy;

- stimulating the development of a synthetic textile (synthetic fabrics);

- stimulating the growth of technical textiles consumption;

- the creation of the eco system of the enterprises for the production of technical textiles and nonwovens in clusters / industrial parks;

- stimulating demand for special and protective clothing and footwear;

- creation of favorable conditions for contract sewing and shoe production;

- reorientation of clothing production on competitive products with the presence of low-cost access to content and a low proportion of manual labor;

- support for the creation of an industrial infrastructure within the footwear industry cluster;

- providing favorable access to functional components manufacturers of clothing and footwear;

- stimulating the production of automotive leather and improve the degree of localization of auto components.

Stage 2. The main activities implemented in the period 2018-2022:

- forming demand for chemical fibers;

- support projects on localization of production of chemical fibers;
- encouraging recycling of the leather industry and the introduction of new technologies to improve the environmental safety of production.

Step 3: Monitoring results and the implementation of cross-cutting initiatives for the period 2023-2025.

If purchasing satisfaction formed by the producer level, that is, its test level formed affordability goods which serves assortment close naturally quality, and due to the level of the consumer, i.e., its test level presupposes the existence of a culture of customer service, attractive products, consumer satisfaction, and, of course, the solvency of the consumers of the respondents who participated in the survey believe that consumer satisfaction is ensured with the reliability of the product, its affordability, the availability of buyers possible make purchases, ie their ability to pay. The natural quality of the products, a variety of product range, attractive design solution, ie fit fashion, products must be sufficiently long warranty period, and interestingly, all respondents were unanimous in saying that the producers fought for respect for him customers to win their trust and willingness to make a purchase just the products of these companies, ie brand and image are always in demand, all of which solves the basic problemprovides consumers with domestic products in the framework of import substitution.

Criteria for evaluation of the light industry enterprises competitiveness through the software developed by the authors for the first time made it possible to formalize the role of experts - respondents on the basis of their competence to the problem. The need for such an approach is due to the desire to have an objective assessment of competence, taking into account not only the views invite experts respondent party to participate in the survey, but also through the evaluation

The results of a survey of experts to assess the competitiveness of enterprises and the competitiveness of the goods of light industry (Table 2 ), although the value obtained coefficient of concordance $(\mathrm{W})$ in the range $0.4-0.6$, but excluding the heretics, that is, those respondents whose opinions do not coincide with the views of the most other experts, we found a pleasant fact that the opinion of the respondents, and those whose credibility is not in doubt, and those who carried the program to heretics, have a unique and intimate view that the factors that characterize their impact on enterprise competitiveness and the competitiveness of the goods are identical, and they can be used in further studies in the estimation of the most competitive enterprises, suggesting that he was able to produce for importsubstituting products for consumers SFD and North Caucasus Federal District regions. Wherein, manufacturers have every reason to these criteria, namely: the ratio of the quality of goods and the cost of production and marketing; the growth rate of sales 


\begin{tabular}{|c|c|c|c|c|c|c|}
\hline \multirow{4}{*}{ Impact Factor: } & ISRA (India) & $=3.117$ & SIS (USA) & $=0.912$ & ICV (Poland) & $=6.630$ \\
\hline & ISI (Dubai, UAE & $=0.829$ & РИНЦ (Russia & $=0.156$ & PIF (India) & $=1.940$ \\
\hline & GIF (Australia) & $=0.564$ & ESJI (KZ) & $=8.716$ & IBI (India) & $=4.260$ \\
\hline & JIF & $=1.500$ & SJIF (Morocec & $=5.667$ & OAJI (USA) & $=0.350$ \\
\hline
\end{tabular}

volume; the cost of innovation; labor productivity; level partnerships stakeholders production of importsubstituting products; the cost of 1 ruble of products sold, and the main criterion; weighted average of product lines of competitive goods treated as withdrawn.

But all respondents experts were unanimous in saying that the company's competitiveness will be sustained over time, if the share of the enterprise market demand is stable. In any case, it will not diminish over time, if it is guaranteed return on investment and, of course, provided a steady return on total assets of Light Industry, engaged in the production of import-substituting products. It justified the opinion of experts, which affects the competitiveness of enterprises and sustainable trade based on direct contractual relations with implementers of those products most enterprises. [6]

\section{Conclusion.}

We agree with them on the question of the role of highly qualified staff, which of course, although it is reflected in the questionnaire as a single criterion the rate of employee turnover - but did not cause the experts, with regret, concern due to the elimination of high schools, colleges, on the basis of which was prepared by highly skilled workers and middle managers - craftsmen, technicians, engineers, technologists engaged in service for outputting not only the innovative technological process, but also innovative equipment. And it is sad that almost stopped training technical personnel, motivating all this lack of demand for them, although the leaders of enterprises at a loss. There is another side to this situation, namely, that the leaders opted out of the preparation of the most highly qualified professionals through targeted training in colleges and universities, unwilling to bear the costs of this same preparation, forgetting the Russian proverb: "miser pays twice." Distressing is the fact that the majority of business leaders believe that all by itself will be resolved, but if a shoemaker, seamstress, machine operator, skornyazhnika you can prepare in the workplace, then prepare a lead engineer - leader and organizer of production of filled processes with effective innovative solution unlikely.

Once again I want to recall another Russian proverb: "As long as the thunder breaks out, peasant will not cross." Do be sure to step on a rake, to receive a severe blow to the forehead and yell - "Ugh, remember the name of this tool, it is a rake." Funny and sad, and still believe in the common sense that truth is more expensive, and the truth will prevail - we will be able to revive this very light industry, which has been proved the experts - respondents showing unanimity on the basic criteria for assessing the competitiveness of enterprises of light industry. It is important that it was the desire of all stakeholders to the unconditional implementation of the planned measures for the rehabilitation of the light industry enterprises in Russia.

\section{References:}

1. Prohorov. V. T., et al. (2014). Quality Revolution: quality through advertising or through real quality: monograph. under the total. Ed. prof. VT Prokhorov (Eds.). ISOiP (branch) DSTU.(p.384). Novocherkassk:YURGPU(NPI).

2. Prohorov, V. T., et al. (2017). under Concept import light industry: background, objectives, innovations: monograph / the total. Ed. Dr. tehn. Sciences, prof. VT Prokhorov (Eds.). Institute of Entrepreneurship and Service sector (branch) of the Don State Technical universiteta. (p.334). Mines: ISOiP (branch) of Dagestan State Technical University.

3. Prokhorov, V. T., et al. (2018). The competiti veness of enterprises and the competitiveness of products - the key to a successful import of goods demanded by consumers SFD and North Caucasus Federal District regions: collective monograph / under the total. Ed. Dr. tehn. Sciences, prof. VT Prokhorov (Eds.). Institute of Entrepreneurship and Service sector (branch) of the Don State Technical universiteta. (p.337). Novocherkassk: Leake.
4. (2018). Quality management through motivation of behavior of light industry enterprise team leader: Monograph / under total. Ed. Dr. tehn. Sciences, prof. VT Prokhorov (Eds.). Institute of Entrepreneurship and Service sector (branch), Don State Technical University. (p.336). Novocherkassk: Leake.

5. Golovko, A. V., et al. (2019). On the possibilities of regulatory documents developed by the Quality Management System (QMS) for the digital production of defect-free importsubstituting products: Monograph / under the total. Ed. Dr. those. Sciences, prof. VT Prokhorov (Eds.). Institute of Entrepreneurship and Service sector (branch), Don State Technical University. (p.227). Novocherkassk: Leake.

6. Golovko, A. V., et al. (2019). Quality Management System - the basis for the production of technical regulation importsubstituting products: monograph / under the total. Ed. Dr. tehn. Sciences, prof. VT Prokhorov (Eds.). Institute of Entrepreneurship and Service sector (branch), Don State Technical University. (p.326). Novocherkassk: YURGPU(NPI). 